\title{
Constraints on ore formation conditions at the Mazra'eh Shadi epithermal deposit, NE Tabriz, Iran: evidences from geochemistry, sulphur isotope, quartz textures and fluid inclusion studies
}

\author{
Kaikhosrov RADMARD ${ }^{1, *}$, Hassan ZAMANIAN ${ }^{1}$, Mohammad Reza HOSSEINZADEH ${ }^{2}$, \\ Ahmad Ahmadi KHALAJI ${ }^{1}$ \\ 1 Lorestan University, Faculty of Natural Sciences, Department of Geology, Khoram Abad, Iran \\ 2 University of Tabriz, Faculty of Natural Sciences, Department of Earth Sciences, Tabriz, Iran
}

\begin{abstract}
Radmard, K., Zamanian, H., Hosseinzadeh, M.R., Khalaji, A.A., 2019. Constraints on ore formation conditions at the Mazra'eh Shadi epithermal deposit, NE Tabriz, Iran: evidences from geochemistry, sulphur isotope, quartz textures and fluid inclusion studies. Geological Quarterly, 63 (2): 230-247, doi: 10.7306/gq.1465

Associate Editor - Justyna Ciesielczuk

The Mazra'eh Shadi deposit is one of the most representative gold deposits in the Ahar-Arasbaran Belt. The main minerals are galena, sphalerite, pyrite and chalcopyrite. Concentrations of Au-Ag occur mainly within quartz veins. Five textures (crustiform, comb, microcrystalline, cockade, and mosaic) are distinguished by field reconnaissance and hand specimen observations. The $\delta^{34} S$ values suggest an increasing role of meteoric water from the deepest levels to the shallow level and surface. Fluid inclusion data show that the mineralisation at the Mazra'eh Shadi deposit can be classified as a volcanic-rock-hosted intermediate-sulphidation epithermal deposit. Fluid inclusions in vein quartz can be distinctly divided into three types according to interpretation of petrographic features: intense boiling, gentle boiling and non-boiling conditions. The presence of intense and gentle boiling among different substages at the same level in the Mazra'eh Shadi deposit indicates that the base of the boiling zone likely shifted upward and downward during vein formation. The concentrations of $\mathrm{Au}-\mathrm{Ag}$ occur mainly within quartz veins in the shallow level with gentle boiling (max. $813 \mathrm{ppb} \mathrm{Au}$ ) and with intense boiling (max. $2420 \mathrm{ppb} \mathrm{Au}$ ), whereas lower Au-Ag concentrations are associated with base metal-rich $(\mathrm{Pb}-\mathrm{Zn})$ in the deepest levels with non-boiling fluids (max. $52 \mathrm{ppb} \mathrm{Au}$ ).
\end{abstract}

Key words: Mazra'eh Shadi, alteration, intense boiling, supersaturation.

\section{INTRODUCTION}

Epithermal gold, base metal and porphyry deposits in Iran are mainly present in two magmatic belts related to the geodynamic evolution of the Tethyan realm between the Arabian and Eurasian plates during the Early Mesozoic-Late Cenozoic: NW-trending Urumieh-Dokhtar magmatic belt (UDMB), and the E-W-trending Alborz Belt (Yang et al., 2009). The Cenozoic Ahar-Arasbaran Belt (AAB) of northwestern Iran is part of the Alborz Magmatic Belt. The Mazra'eh Shadi deposit is located in $A A B$, northern Iran, which is located $\sim 130 \mathrm{~km}$ north-east of Tabriz in the Alborz Magmatic Belt geostructural zone (Fig. 1). Large Cu-Mo porphyry deposits, Cu-skarn occurrences, and Cu-Mo-Au epithermal-vein deposits in this area indicate economic value and potential of mineralisation in this

\footnotetext{
* Corresponding author, e-mail: k_radmard@yahoo.com Received: February 22, 2018; accepted: February 9, 2019; first published online: May 17, 2019
}

magmatic belt and hence requirement of more systematic studies of metallogenesis and earth resource exploration. Quartz generally is a dominant gangue mineral associated with epithermal vein deposits and reflects different hydrothermal fluid conditions. Therefore, quartz textures have been considered by many researchers to correspond to the evolution of hydrothermal systems (Saunders, 1994; Bobis et al., 1995; Dong and Zhou, 1996; Shimizu et al., 1998; Moncada et al., 2012). A common trend detected in hand specimens of quartz is that its texture varies from typically coarsely crystalline at depth to fine-grained and microcrystalline at shallow levels of epithermal vein systems (Dowling and Morrison, 1989; Hedenquist et al., 2000; Simmons et al., 2005; Christie et al., 2007). Quartz textures in hand-scale sizes of ore samples were selected to show the textural characteristics. The studies on the Mazra'eh Shadi mineralisation have been limited providing little insight into the origin of the deposit. In this paper, we describe the geological setting and geochemical characteristics of the Mazra'eh Shadi deposit, including fluid inclusions, quartz textures and sulphur isotopic characteristics, and propose a genetic model for the deposit and guidelines for future exploration in the $A A B$. 


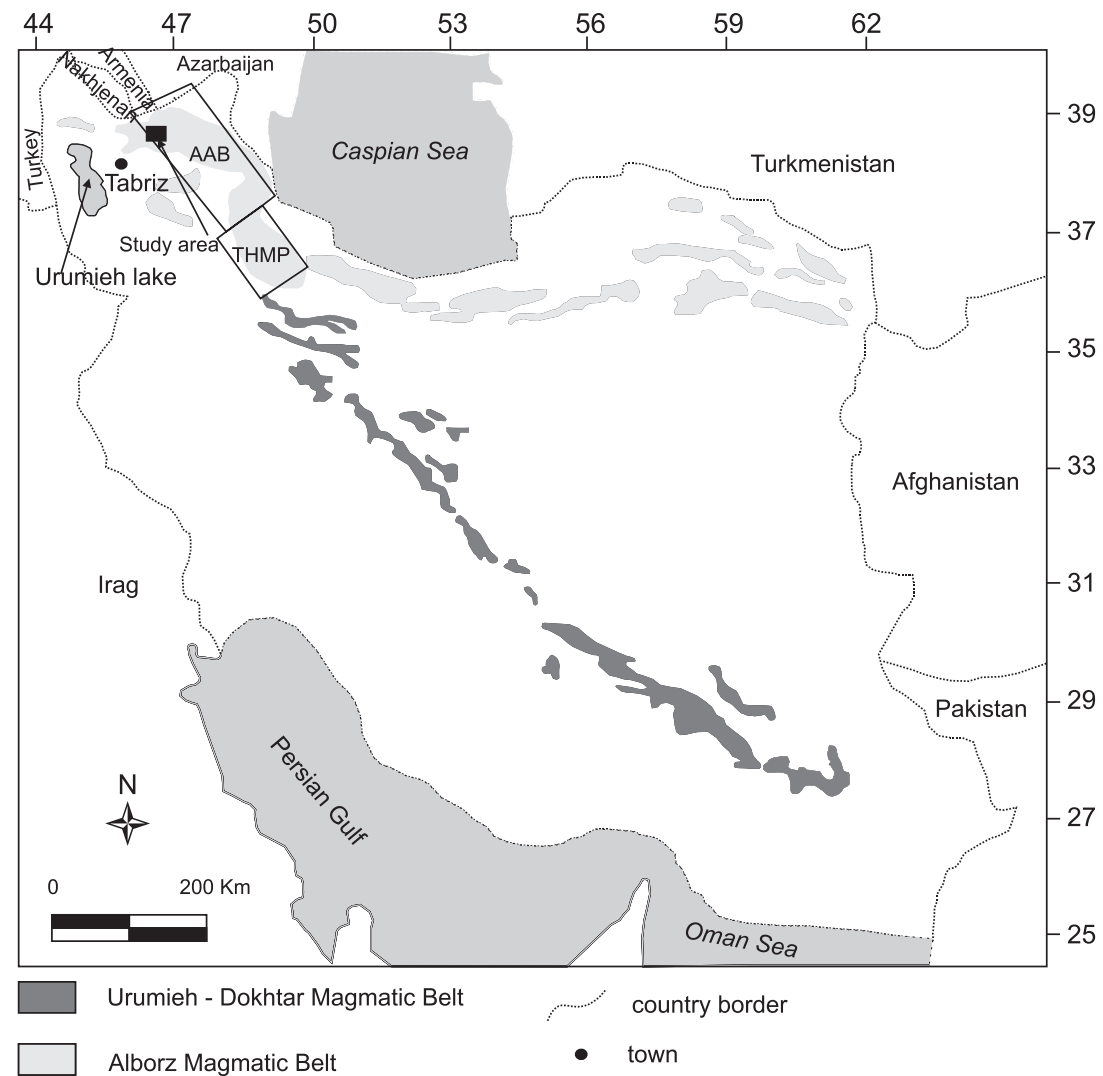

Fig. 1. A simplified regional geotectonic map of Iran (Nabavi, 1976)

Location of studied area is marked by black rectangle. Location of the Ahar-Arasbaran Belt in the Alborz Magmatic Belt (NW Iran) that is subdivided into the Ahar-Arasbaran Belt in the north and Tarom-Hashtjin metallogenic province (THMP) in the south (Azizi and Jahangiri, 2008; Azizi and Moinevaziri, 2009)

\section{GEOLOGY}

The Alborz Magmatic Belt in northern Iran is divided into the western and eastern parts (Azizi and Jahangiri, 2008; Azizi and Moinevaziri, 2009). The eastern zone consists of basic and felsic tuffs and lavas with alkaline to shoshonitic affinities (Blourian, 1994), whereas the western part consists of andesitic to dacitic lavas and many calc-alkaline to shoshonitic granitoid bodies. The western part is subdivided into two mineralized provinces, the AAB in the north and the Tarom-Hashtjin metallogenic province in the south (Fig. 1).

The Cenozoic AAB hosts precious and base metal mineralisation (Daliran et al., 2007), including porphyry, skarn, and epithermal copper, molybdenum, and gold deposits. According to the distribution of the ore deposit types, three different metallogenic zones are distinguished within the AAB (Fig. 2). The three zones are (Jamalia et al., 2010):

- Zone A contains $\mathrm{Cu} \pm \mathrm{Mo} \pm$ Au porphyry and skarn and stockwork Cu-Mo-Au mineralisation types (Daliran et al., 2007). The Sungun, Anjerd and Mazra'eh mines from west to east are located in this zone.

- Several epithermal gold occurrences (Mazra'eh Shadi, Safikhanlu, Sarilar and Zaglic mines) are located in Zone B. Prominent examples of this type of mineralisation are hosted by the Eocene volcanic rocks (Daliran et al., 2007).
- Zone $\mathrm{C}$ deposits occur in the mountain range from the Sabalan volcano in the south-east to the Jolfa region in the north-west. The main examples include the Masjed Daghi and Miveh Rud (Daliran et al., 2007).

Widespread, WNW-trending alteration zones that are parallel to the regional faults occur mainly within the Eocene volcanic rocks in Mazra'eh Shadi in Zone B. Considering the alteration assemblages, vein minerals, and fluid inclusion data, Ebrahimi et al. (2009) recognized different types of epithermal systems in the AAB, as follows (Fig. 2):

- low-sulphidation (Safikhanlu and Zaglic);

- intermediate (e.g., Mazra'eh Shadi);

- high-sulphidation (e.g., Masjed Daghi).

Geologically, the study area consists of three rock suites (Fig. 3; Radmard et al., 2017):

- eocene pyroclastic rocks, especially tuffs and andesitic lavas;

- oligocene-Pliocene pyroclastic rocks, acidic domes, and dykes of andesitic and dacitic compositions;

- quaternary volcanogenic conglomerate (agglomerate) and alluvial units.

The oldest rocks in this area are Eocene pyroclastics, which are covered by Oligocene and Pliocene volcanic rocks. They comprise andesite and trachyandesite. Numerous dacite to andesitic dykes and stocks intruded into the Upper Eocene vol- 


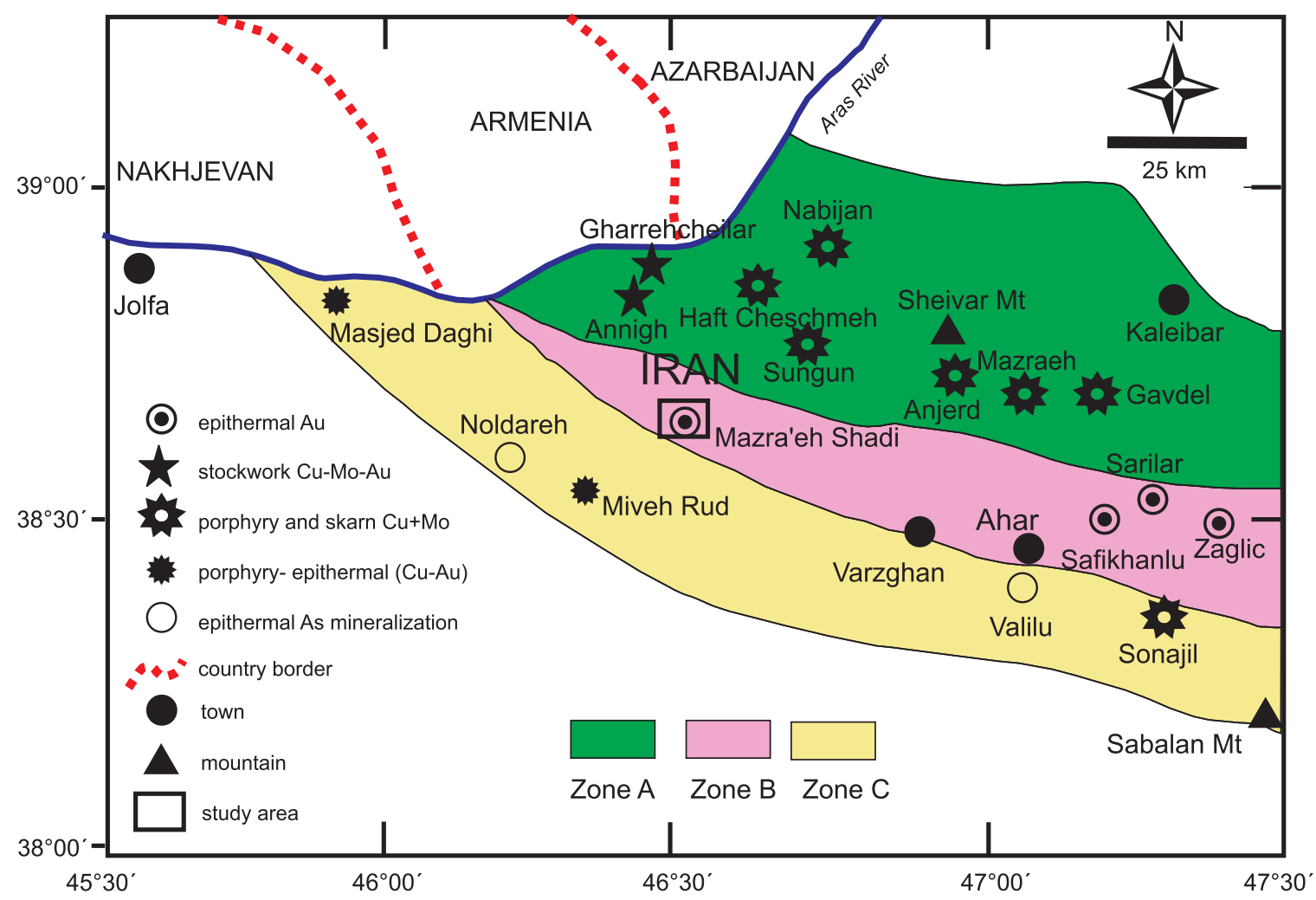

Fig. 2. Distribution of different metallogenic zones and mineralisation in the Cenozoic Ahar-Arasbaran Belt exposed in northwestern Iran (Jamalia et al., 2010)

canic complex. The youngest formation in the area is Quaternary alluvial sediments. The Quaternary volcanogenic agglomerate (lahar) widely crops out in the vicinity of Mazra'eh Shadi in the southeastern part of the study area (Fig. 3A). Subvolcanic rocks, such as quartz monzodiorite - diorite porphyry (mdp), intruded into Eocene volcanic and volcano-sedimentary units and caused mineralisation and alteration of these units.

Gold mineralisation in the Mazra'eh Shadi region is related to Eocene volcanic and intrusive rocks. Outcrops of the subvolcanic rocks extend over about $1650 \mathrm{~m}$ and show a width of about 300-450 m west of Hizehjan (Radmard et al., 2017). The locations of samples are shown in Figure 3B.

The main structure in the Ahar-Arasbaran metallogeny region formed as result of the Alpine Orogeny, especially during the Cretaceous Laramid phase (Radmard et al., 2017). The evolution of this region has been a controversial issue. While some authors consider this region as an integral part of the UDMB, based on similarities in the geochemistry of the volcanic-plutonic rocks (Nogol-Sadat, 1993), others argue for a rift setting (Riou, 1979) or a rift and collision-related setting (e.g., Moayyed et al., 2008). The UDMB is dominated by calc-alkaline volcanic and plutonic rocks and is considered an Andean-type magmatic belt generated by NW-dipping subduction of Neo-Tethyan oceanic crust beneath the Central Iranian micro-continent, and the collision of the African and Eurasian plates during the Alpine Orogeny in the Paleogene (Berberian and King, 1982). The deposits, which are formed from the surface to approximately $400 \mathrm{~m}$ below the surface, are typified by veins, stockworks and disseminations.
The hydrothermal activity and the presence of the faults and highly fractured breccia zone caused a variety of alteration in the Mazra'eh Shadi deposit. Field mapping, microscopic study and XRD analysis resulted in recognition of five, zonally distributed hydrothermal alteration assemblages that consist of propylitization, phyllic, argillic and advanced argillic alterations associated with silicification and ore deposition. Generally, the outcrops of the silicification can be divided into three main forms; as stockwork in the northeastern part of the area; as distinct silica caps in outcrops of the central and southwestern part; as silica veins with a $20^{\circ} \mathrm{N}-80^{\circ} \mathrm{E}$ trend in the southwestern part (Radmard et al., 2017).

\section{MATERIAL AND METHODS}

More than 100 samples have been collected from surface and drill core samples in the Mazra'eh Shadi region. Laboratory works began with preparation of thin and polished sections from 95 samples which were studied by optical microscopy at Tabriz University. For determination of the major rock-forming minerals in the ores, 63 samples were selected for X-ray diffraction (XRD) and analysed by a SIEMENS model D-5000 diffractometer with CuK $\alpha$ radiation, voltage $40 \mathrm{kV}$, beam current $80 \mathrm{~mA}$, continuous scanning, scanning speed $8^{\circ} / \mathrm{min}$, scan range $2-70^{\circ}$, slit DS SS $-1^{\circ}$, ambient temperature $18^{\circ} \mathrm{C}$, and humidity $30 \%$ in the Binalod laboratory (Iran). Rock samples were crushed to 200-mesh size particles in an agate mill. Unaltered igneous rocks (16 samples, Appendix $1^{*}$ ) were selected for XRD from host 


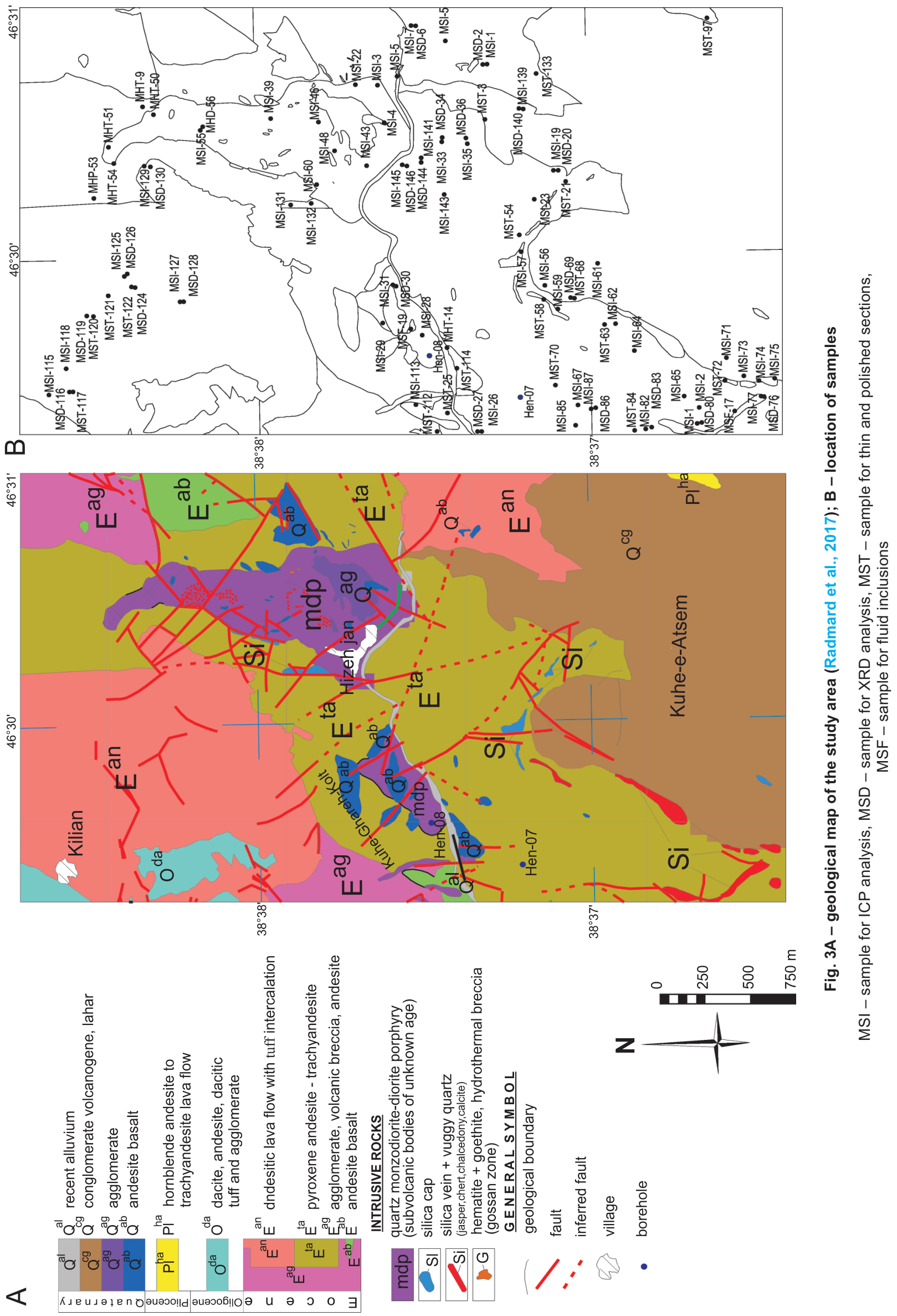


rocks. The chemical analyses (inductively coupled plasma mass spectrometry - ICP-MS) were performed in the Amdel laboratory (Australia) and the ALS Chemex Canada for 51 samples. Gold content was determined by inductively coupled plasma optical emission spectrometry (ICP-OES). Detection limits for the elements are: $\mathrm{Au}-1 \mathrm{ppb}, \mathrm{Ag}-0.2 \mathrm{ppm}, \mathrm{Pb}, \mathrm{Zn}$ and $\mathrm{Cu}-0.5 \mathrm{ppm}$. Over 500 Scanning Electron Microscopy with Energy Dispersive Spectroscopy (SEM-EDS) analyses on a Field Emission microscope were used in this study. The SEM-EDS analyses were performed at the Department of Metallurgical and Materials Engineering, Lorestan University (Lorestan/Iran). Electron microprobe analyses (EPMA) of the polished and thin-polished sections were performed in the Imidro laboratory (Iran) by a Cameca SX100 at IMPRC. Operating conditions were: $20 \mathrm{kV}$ and $20 \mathrm{nA}$, with a beam diameter 1-5 $\mu \mathrm{m}$.

Ten samples containing quartz veinlets from drill holes (Hen-07 and Hen-08 boreholes) and surface samples were selected for thermometric analyses. Microthermometric studies were carried out at the Lorestan University Geological Department-Fluid Inclusion Laboratory by a Linkam THMSG600 freezing-heating stage mounted on an Olympus microscope. They were conducted on 100-150 $\mu \mathrm{m}$ thick polished slabs prepared from 10 quartz samples from the silicified and mineralized zones. Most samples were from gold-rich and quartz-sulphide breccia veins. The precision of temperature measurements is $\sim \pm 0.1^{\circ} \mathrm{C}$ on cooling runs and $\pm 2^{\circ} \mathrm{C}$ on heating runs and the temperature range varies from -196 to $600^{\circ} \mathrm{C}$. Salinities of liquid-rich fluid inclusions were calculated from the measured ice-melting temperatures (Bodnar, 1993). Interpolation of data was done by implementing the Kriging interpolation function built in the Surfer software, version 9, Excel, computer aided design (Auto CAD), Fluids (Bakker, 1999), Clathrates (Bakker, 1997), and Flincore (Brown, 1989). The basic statistics, minimum, maximum, mean and standard deviation were calculated by SPSS software, version 16 .

The sulphur isotope compositions were examined in 11 pyrite samples (from the Hen-07 borehole). Representative pyrite-rich samples from the ore stage vein materials were analysed for sulphur isotope ratios at the G. G. Hatch Stable Isotope Laboratories, University of Ottawa. The analytical precision is $\pm 0.2 \%$.

\section{RESULTS}

Igneous rocks in the Mazra'eh Shadi deposit include andesite, trachyandesite to andesitic basalts. These rocks contain $\sim 21$ to $30 \%$ phenocrysts of plagioclase (oligoclase-andesine) and hornblende (Fig. 4).

The sulphur isotopic values of pyrite are in a range from -0.2 to $0.7 \%$, but they are concentrated in the range of 0.2 to $0.7 \%$. The $\delta^{34} S$ value of the fluid was calculated from $\delta^{34} S$ value of pyrite, and the mineral $\delta^{34} \mathrm{~S}$ versus $\mathrm{H}_{2} \mathrm{~S}$ fractionation factor (Ohmoto and Rye, 1979) was estimated assuming $\mathrm{H}_{2} \mathrm{~S}$ as the main sulphur species in the fluid (Table 1).

Microthermometric studies were performed on primary inclusions in quartz samples. The fluid inclusions are round and are mostly liquid-rich two-phase ones. The inclusions have a wide variation in size from 4 to $93 \mu \mathrm{m}$ with an average of $14 \mu \mathrm{m}$. The largest fluid inclusion of $93 \mu \mathrm{m}$ was observed in the outcrop sample (MSF-17). Homogenization temperatures of the inclusions in quartz, which were commonly observed either as inclusions along growth zones or isolated single inclusions in crystals, vary between 160 and 324 in drill core samples and between 176 and $302^{\circ} \mathrm{C}$ in surface outcrops, with an average of $228^{\circ} \mathrm{C}$ for samples from both drill core and surface outcrops (Radmard et al., 2017). The ice melting temperatures vary from -0.1 to $-3.2^{\circ} \mathrm{C}$, which correspond to a salinity range from 0.17 to $5.17 \mathrm{wt} . \% \mathrm{NaCl}$ equivalent with an average of $1.9 \mathrm{wt} . \%$. The microthermometric data (homogenization temperatures, ice melting temperatures and size for fluid inclusions) and calculated parameters, such as salinities and density, are summarized in Appendix 2.

Three main types of fluid inclusions were identified at room temperature $\left(25^{\circ} \mathrm{C}\right)$ in the samples from silicified and mineralized zones. In order of abundance, they are as follows:

Type 1 - liquid-rich (LV). Inclusions of this type are filled by liquid + vapour with the liquid phase volumetrically dominant and lack of daughter crystals. These fluid inclusions are common in all mineralized quartz veins. The diameters of these fluid inclusions range from 4 to $93 \mu \mathrm{m}$. Liquid-rich inclusions (75-80\% filling degree) occur in almost all samples and make the largest numbers of the studied inclusions. The last ice-melting temperature $\left(\mathrm{Tm}\right.$, ice) of these inclusions is between -0.1 and $-3.2^{\circ} \mathrm{C}$. These inclusions yield homogenization temperatures from 160 to
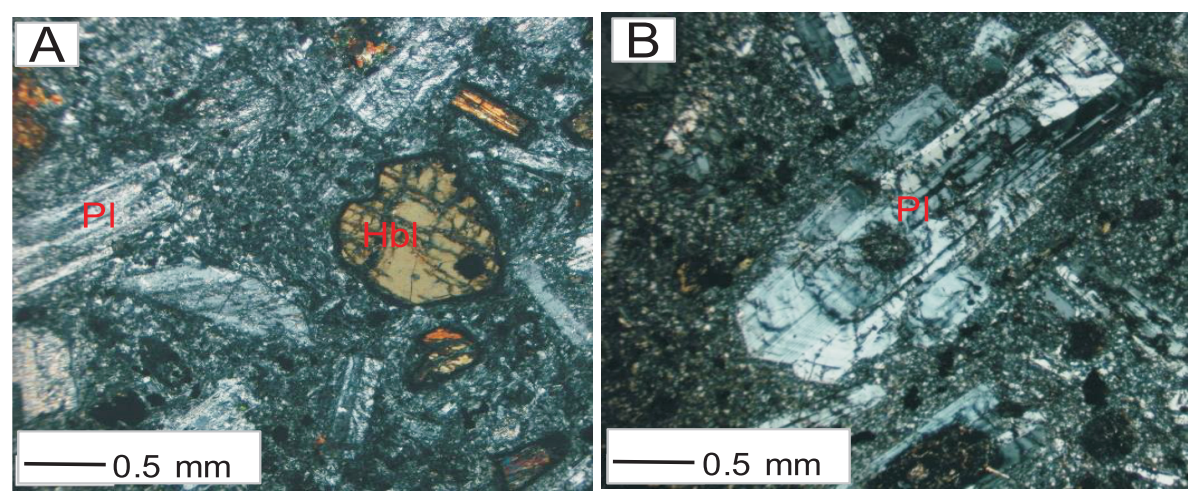

Fig. 4. Photomicrographs of host-rock andesite (XPL)

A - plagioclase and hornblende are major constituents in porphyritic andesite;

B - porphyritic andesite with fresh plagioclase phenocrysts;

$\mathrm{XPL}$ - cross-polarized light, $\mathrm{Pl}$ - plagioclase, $\mathrm{Hbl}$ - hornblende 
Sulphur isotope data of sulphides (pyrite in the main stage mineralisation) from the Mazra'eh Shadi deposit

\begin{tabular}{|l|c|c|c|c|c|}
\hline $\begin{array}{c}\text { Sample } \\
\text { No. }\end{array}$ & Vein mineralogy & $\begin{array}{c}\mathrm{T} \\
{\left[{ }^{\circ} \mathrm{C}\right]}\end{array}$ & $\begin{array}{c}\delta^{34} \mathrm{~S} \mathrm{V-CDT} \\
{[\%]}\end{array}$ & $\begin{array}{c}\delta^{34} \mathrm{~S} \mathrm{H}_{2} \mathrm{~S} \\
{[\% \text { ] }}\end{array}$ & $\begin{array}{c}\text { Depth } \\
{[\mathrm{m}]}\end{array}$ \\
\hline $1 \mathrm{MS}$ & Qtz-Mo-Ccp-Py-Sp-Gn & 243.7 & 0.6 & -0.9 & 155 \\
\hline $2 \mathrm{MS}$ & Qtz-Py & 220.4 & 0.3 & -1.3 & 55 \\
\hline $3 \mathrm{MS}$ & Qtz-Mo-Ccp-Py-Sp-Gn & 243.7 & 0.7 & -0.8 & 155 \\
\hline $4 \mathrm{MS}$ & Qtz-Py & 219.0 & -0.2 & -1.9 & surface \\
\hline $5 \mathrm{MS}$ & Qtz-Py & 219.0 & 0.1 & -1.6 & surface \\
\hline $6 \mathrm{MS}$ & Qtz-Py & 219.0 & 0.1 & -1.6 & surface \\
\hline $7 \mathrm{MS}$ & Qtz-Mo-Ccp-Py-Sp-Gn & 243.7 & 0.7 & -0.8 & 155 \\
\hline $8 \mathrm{MS}$ & Qtz-Py & 220.4 & 0.4 & -1.2 & 55 \\
\hline $9 \mathrm{MS}$ & Qtz-Mo-Ccp-Py-Sp-Gn & 243.7 & 0.7 & -0.9 & 155 \\
\hline $10 \mathrm{MS}$ & Qtz-Py & 220.4 & 0.2 & -1.4 & 55 \\
\hline $11 \mathrm{MS}$ & Qtz-Py & 219.0 & 0.3 & -1.4 & surface \\
\hline
\end{tabular}

Ccp - chalcopyrite, Gn - galena, Mo - molybdenite, Py - pyrite, Qtz - quartz, Sp - sphalerite; T is based on microthermometric measurements of fluid inclusions in quartz; $\delta^{34} S \mathrm{H}_{2} \mathrm{~S}$ values are calculated based on $\mathrm{H}_{2} \mathrm{~S}$-sulphide sulphur isotope fractionation equations of Ohmoto and Rye (1979)

$308^{\circ} \mathrm{C}$ and the salinities are $0.17-5.2 \mathrm{wt} . \% \mathrm{NaCl}$ equivalent. This type occurs widely in quartz with zonal texture.

Type 2 - two-phase vapour-rich (VL). Inclusions of this type are common in the outcrop quartz vein samples. The diameters of these fluid inclusions range from 6 to $31 \mu \mathrm{m}$. Their last ice-melting temperature ( $\mathrm{Tm}$, ice) is between -0.1 and $-1.1^{\circ} \mathrm{C}$. These inclusions homogenized into the gas phase. The homogenization temperatures range from 173 to $324^{\circ} \mathrm{C}$, which is relatively the highest homogenization temperature range obtained in the study area, and the related salinities are $0.16-1.8$ wt. \% $\mathrm{NaCl}$ equivalent. The gas bubble in (VL) inclusions occasionally occupies $>80 \%$ of the inclusion volume. This type is common in quartz with comb texture and mosaic texture.

Type 3 - vapour monophase (V). Inclusions of this type have diameters ranging from 10 to $30 \mu \mathrm{m}$.

\section{DISCUSSON}

\section{PETROGRAPHIC AND GEOCHEMICAL CHARACTERISTICS OF HOST ROCKS}

Unaltered igneous rocks associated with the Mazra'eh Shadi deposit (16 out of 51 samples; Appendix 1) are distributed in the subalkaline field on the total alkalis versus silica diagram (Le Maitre, 2002), spanning from dacite, andesite to basaltic andesite (Fig. 5A). Igneous rocks typically associated with epithermal deposits worldwide include andesitic components (Arribas, 1995; Simmons et al., 2005) and show subalkaline affinity (Du Bray, 2014) comprising the basalt-rhyolite span (Fig. $5 \mathrm{~A})$. Igneous rocks associated with quartz-adularia epithermal deposits have $\mathrm{SiO}_{2}$ contents that range continuously to as low as $\sim 48 \mathrm{wt} . \% \mathrm{SiO}_{2}$, and the $\mathrm{SiO}_{2}$ contents of the principal igneous rock population associated with quartz-alunite epithermal deposits only increase to $\sim 54 \mathrm{wt} . \%$. Silica contents of igneous rocks associated with quartz-adularia deposits, which range to values about $\sim 6 \%$ less than those of igneous rocks associated with quartz alunite deposits, are distinct and constitute the principal geochemical difference between igneous rocks associated with the two epithermal deposit types.

Many of the igneous rocks associated with epithermal deposits have $\mathrm{Sr} / Y$ greater than $\geq 20$ (Fig. 5B) which is characteristic of magmas with adakitic compositions; these compositions are also consistent with greater magmatic water contents. In the $\mathrm{Sr} / \mathrm{Y}$ versus $\mathrm{Y}$ (ppm) diagram (Defant and Drummond, 1993), more than half of the Mazra'eh Shadi samples associated with epithermal deposits have adakitic compositions with $\mathrm{Sr} / \mathrm{Y}>20$ (Fig. 5B).

Hornblende preferentially incorporates $\mathrm{Y}$ and therefore hornblende crystallisation and fractionation result in progressively depleted Y contents (Sisson, 1994). Greater magmatic Sr contents result from suppressed crystallisation of plagioclase, which preferentially incorporates $\mathrm{Sr}$ and, consequently, the greater $\mathrm{Sr} / \mathrm{Y}$ indicates crystallisation of hornblende and suppression of plagioclase crystallisation, both consistent with greater magmatic water contents that are ultimately conducive to the magmatic volatile exsolution required to generate the magmatic hydrothermal fluids responsible in epithermal systems. In the $\mathrm{Rb}$ versus $(\mathrm{Y}+\mathrm{Nb})$ tectono-magmatic discrimination diagrams (Pearce et al., 1984), most of the igneous rocks associated with epithermal deposits fall in the volcanic arc granites field. However, some of the igneous rocks associated with the Midas quartz-adularia gold-silver deposit (Nevada) suggest a within-plate affinity (John, 2001). In this diagram, all Mazra'eh Shadi samples fall in the volcanic arc granites field (VAG; Fig. 5C).

In the $\mathrm{Na}_{2} \mathrm{O}+\mathrm{K}_{2} \mathrm{O}-\mathrm{CaO}$ versus $\mathrm{SiO}_{2}$ variation diagram (quartz adularia or quartz alunite deposits) the Mazra'eh Shadi samples are distributed (Fig. 6) in the calcic field (62.5\%) to calc-alkalic field (31.5\%). Igneous rocks typically associated with epithermal deposits containing 50 to $\sim 65 \mathrm{wt} \% \% \mathrm{SiO}_{2}$ are calcic to calc-alkalic, whereas samples with $>65$ wt. $\% \mathrm{SiO}_{2}$ are generally calc-alkalic to alkali-calcic (Frost et al., 2001). However, most of the igneous rocks associated with epithermal deposits worldwide are calc-alkaline in terms of IUGS classification. 

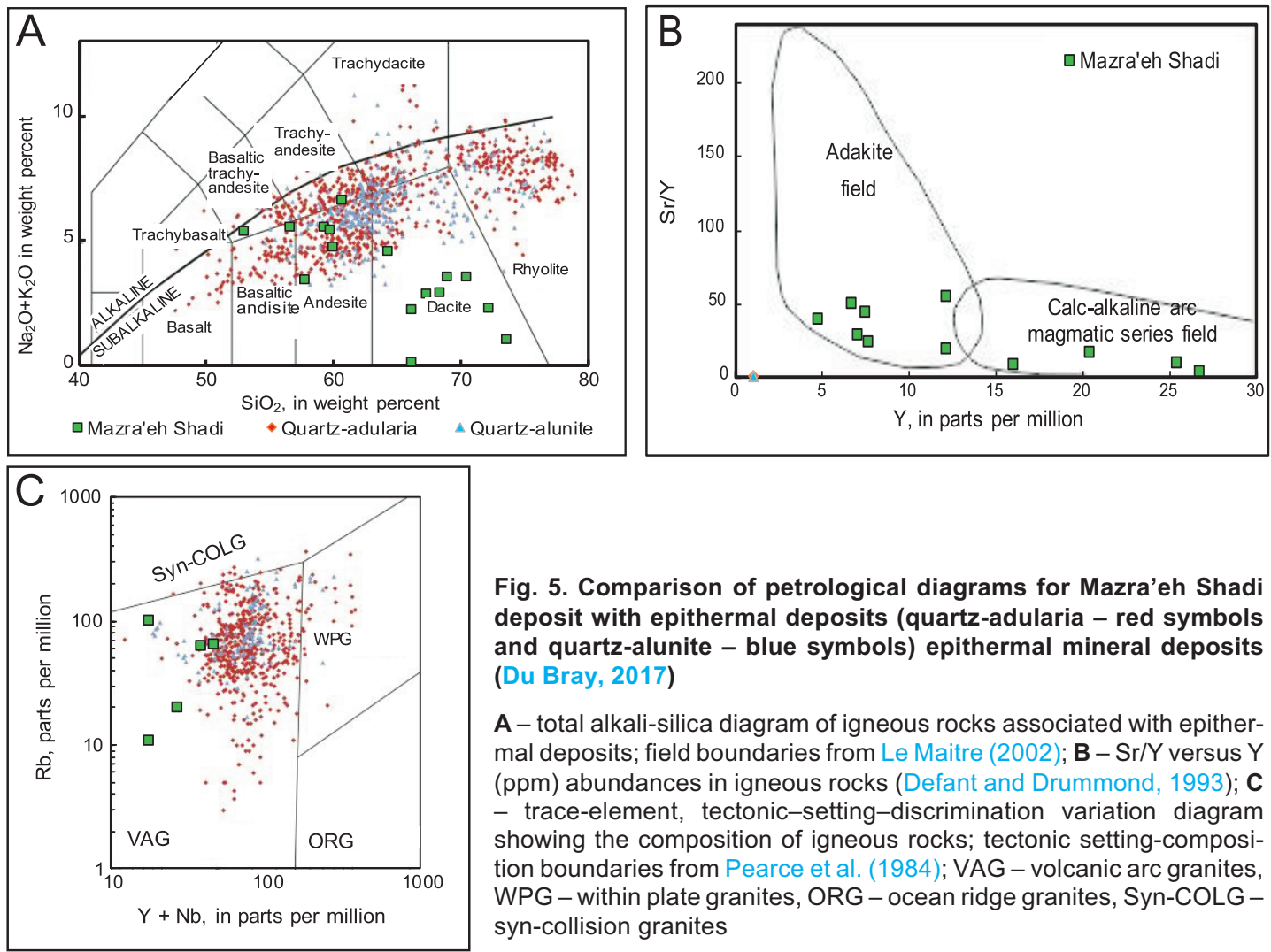

Fig. 5. Comparison of petrological diagrams for Mazra'eh Shadi deposit with epithermal deposits (quartz-adularia - red symbols and quartz-alunite - blue symbols) epithermal mineral deposits (Du Bray, 2017)

A - total alkali-silica diagram of igneous rocks associated with epithermal deposits; field boundaries from Le Maitre (2002); B - Sr/Y versus Y (ppm) abundances in igneous rocks (Defant and Drummond, 1993); C - trace-element, tectonic-setting-discrimination variation diagram showing the composition of igneous rocks; tectonic setting-composition boundaries from Pearce et al. (1984); VAG - volcanic arc granites, WPG - within plate granites, ORG - ocean ridge granites, Syn-COLG syn-collision granites

Comparison of the Mazra'eh Shadi $\mathrm{Na}_{2} \mathrm{O}+\mathrm{K}_{2} \mathrm{O}-\mathrm{CaO}$ versus $\mathrm{SiO}_{2}$ and major oxides $\left.\left(\mathrm{TiO}_{2} / \mathrm{SiO}_{2}, \mathrm{Al}_{2} \mathrm{O}_{3} / \mathrm{SiO}\right)_{2}\right)$ values with published data from some epithermal deposits (21 quartz adularia deposits and 15 quartz alunite deposits; Du Bray, 2017) shows similarity to the quartz-adularia epithermal mineral deposits (Figs. 6 and 7).

In low- $\mathrm{SiO}_{2}$ igneous rocks associated with epithermal deposits, concentrations of $\mathrm{TiO}_{2}$ and $\mathrm{Al}_{2} \mathrm{O}_{3}$ vary considerably, but they decrease in a more siliceous variety (Fig. 7). The relationship between $\mathrm{TiO}_{2}$ and $\mathrm{SiO}_{2}$ is interpreted as a function of crystallisation and fractionation of clinopyroxene, hornblende, biotite, and Fe-Ti oxide (Du Bray, 2017). Plots of $\mathrm{TiO}_{2}$ or $\mathrm{Al}_{2} \mathrm{O}_{3}$ versus $\mathrm{SiO}_{2}$ for Mazra'eh Shadi samples are consistent with the quartz-adularia epithermal type worldwide (Du Bray, 2014). The results of electron probe microanalyses of quartz are summarized in Table 2.

\section{MINERALISATION}

The mineralisation is restricted to silica veins and locally to the stockwork (Fig. 8A, B). The ore minerals occur as disseminations, massive accumulations, and the matrix of hydrothermally brecciated (Fig. 8C) and silicified volcanic rocks.

Mineralisation occurs exclusively along Hizehjan village in the eastern part of the area. The main minerals are galena, sphalerite, pyrite and chalcopyrite (Fig. 8D, E). Ore and gangue minerals assemblages identified in the Mazra'eh Shadi deposits are typical of mineralisation of epithermal origin (Radmard et al., 2017).

At the Mazra'eh Shadi deposit, Au concentrations occur mainly within quartz veins (Fig. 8F) in a shallow level $(65 \mathrm{~m}$ b.s.l.), whereas lower Au contents are associated with base metal-rich deeper levels $(280-155 \mathrm{~m})$. Pyrite is the most abundant sulphide mineral (Fig. 8G-I).
According to the petrographic features and cross-cutting relationships, it is possible to distinguish three main stages of quartz mineralisation (Fig. 9). The intermediate stage appears to be the most productive in noble metals. It is distributed in three spatial domains differing with mean gold contents and deduced boiling conditions:

$$
\begin{aligned}
& \text { a - deepest levels ( } 155 \mathrm{~m} \text { with } 52 \mathrm{ppb} \text { Au and no evi- } \\
& \text { dence of boiling), } \\
& \text { b-shallow levels ( } 65 \mathrm{~m} \text { with } 813 \mathrm{ppb} \text { Au and gentle boil- } \\
& \text { ing), } \\
& \mathrm{c} \text { - surface (with } 2420 \mathrm{ppb} \text { Au and intense boiling). }
\end{aligned}
$$

\section{ORE TEXTURES}

Ore textures are highly variable. Ore minerals textures are massive, disseminated, replacement, banded (open-space filling), and stockwork. The mineralisation includes mainly Au-Ag-bearing quartz veins within andesite and trachyandesite, which is controlled by fault distribution (Radmard et al., 2017). The quartz veins consist mainly of fine- to coarse-grained quartz or quartz and base metal sulphides with minor chalcedony. Geochemical analyses of altered andesite and trachyandesite in the northern Mazra'eh Shadi show distinct anomalies of $\mathrm{Au}, \mathrm{Pb}, \mathrm{Ag}$, $\mathrm{Cu}$ and Zn (Radmard et al., 2017). Sulphide minerals consist mainly of pyrite associated with gold, whereas free gold grains occur rarely in silica veinlets. Gold at Mazra'eh Shadi is mostly invisible and could be mainly traced by chemical analysis.

\section{QUARTZ TEXTURE}

In this study, the term "texture" is used for features observed in hand specimens and in microscopic scale to document morphological variations of vein quartz at the Mazra'eh Shadi deposit (e.g., Dowling and Morrison, 1989; Barton, 1991; Bobis, 

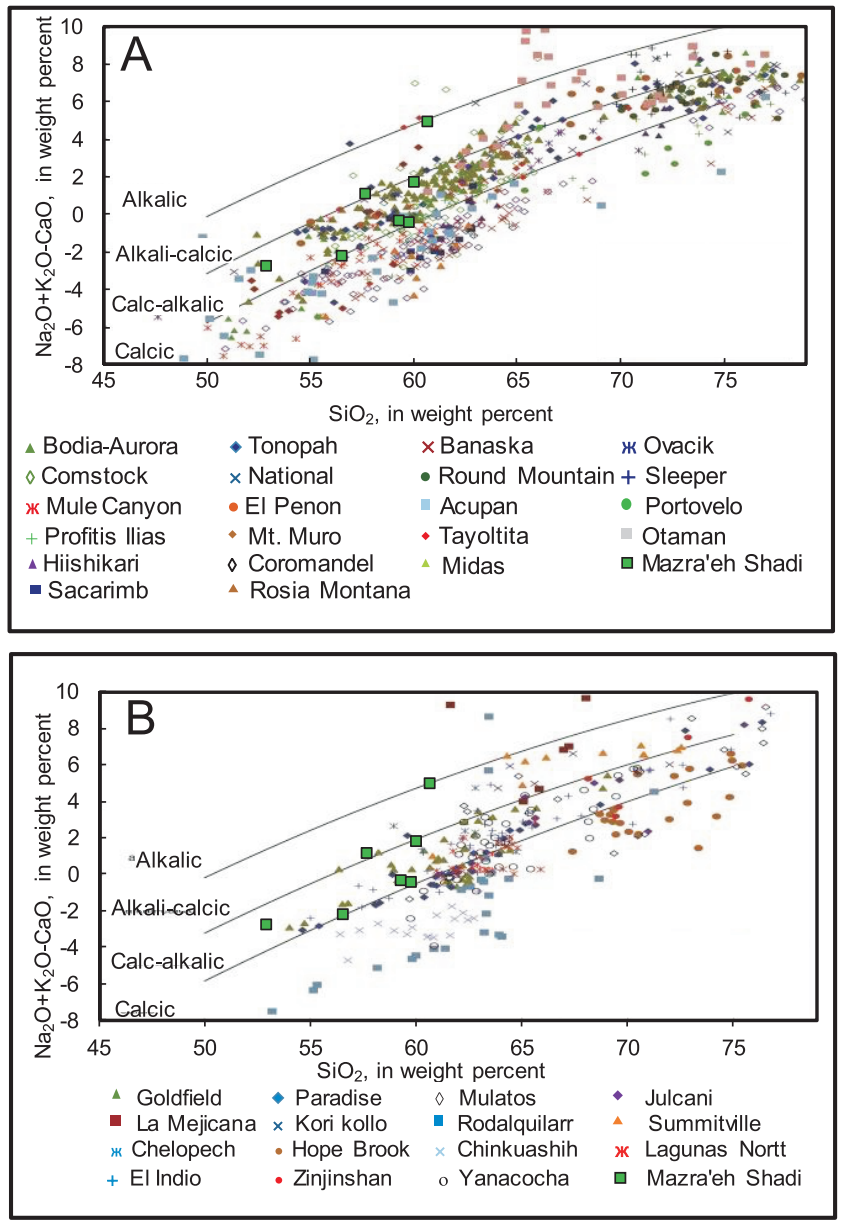

Fig. 6. Comparison of $\mathrm{Na}_{2} \mathrm{O}+\mathrm{K}_{2} \mathrm{O}-\mathrm{CaO}$ versus $\mathrm{SiO}_{2}$ diagram of igneous rocks associated in Mazra'eh Shadi deposit with epithermal mineral deposits

A - associated with quartz-adularia deposits; B - associated with quartz-alunite deposits (Du Bray, 2017); boundaries between various rock series from Frost et al. (2001)
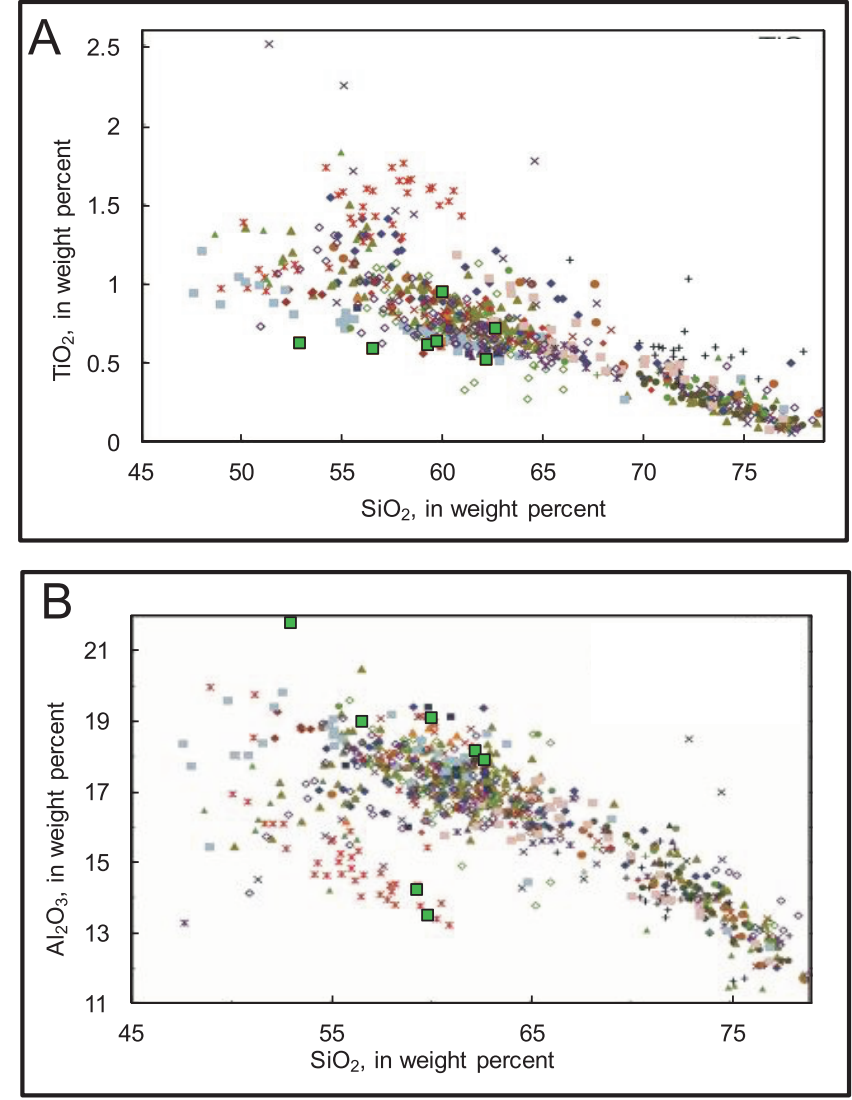

Fig. 7. Variation diagrams showing abundances of major oxides $\left(\mathrm{TiO}_{2} / \mathrm{SiO}_{2}, \mathrm{Al}_{2} \mathrm{O}_{3} / \mathrm{SiO}_{2}\right)$ in igneous rocks associated with quartz-adularia epithermal mineral deposits

Symbols are the same as those in Figure 6A (Du Bray, 2017)

Results of electron microprobe analyses of quartz [wt.\%]

\begin{tabular}{|c|c|c|c|c|c|l|l|l|l|l|l|l|}
\hline $\begin{array}{c}\text { Point. } \\
\text { No. }\end{array}$ & Location & $\mathrm{Na}_{2} \mathrm{O}$ & $\mathrm{K}_{2} \mathrm{O}$ & $\mathrm{MgO}$ & $\mathrm{CaO}$ & $\mathrm{MnO}$ & $\mathrm{FeO}$ & $\mathrm{Al}_{2} \mathrm{O}_{3}$ & $\mathrm{SiO}_{2}$ & $\mathrm{TiO}_{2}$ & $\mathrm{P}_{2} \mathrm{O}_{5}$ & Total \\
\hline 1 & MSF19 & 0.08 & 0.09 & 0.04 & 0.01 & 0 & 0.03 & 0.57 & 98.99 & 0 & 0 & 99.83 \\
\hline 3 & MSF19 & 0 & 0 & 0.01 & 0 & 0.01 & 0.03 & 0.4 & 99.39 & 0.02 & 0 & 99.86 \\
\hline 4 & MSF19 & 0.04 & 0.03 & 0.03 & 0.01 & 0 & 0 & 0.14 & 99.12 & 0 & 0.03 & 99.4 \\
\hline 6 & Hen-08-D143 & 0 & 0 & 0.05 & 0.01 & 0.02 & 0.02 & 0.12 & 99.85 & 0 & 0 & 100.1 \\
\hline 9 & Hen-08-D143 & 0 & 0.02 & 0 & 0 & 0.02 & 0 & 0.09 & 98.94 & 0 & 0.03 & 99.1 \\
\hline 15 & Hen-08-D143 & 0 & 0 & 0 & 0.03 & 0 & 0.04 & 0.08 & 99.37 & 0 & 0.04 & 99.56 \\
\hline 26 & Hen-07-D176 & 0.02 & 0 & 0 & 0 & 0 & 0.06 & 0.18 & 99.54 & 0.09 & 0.01 & 99.9 \\
\hline
\end{tabular}



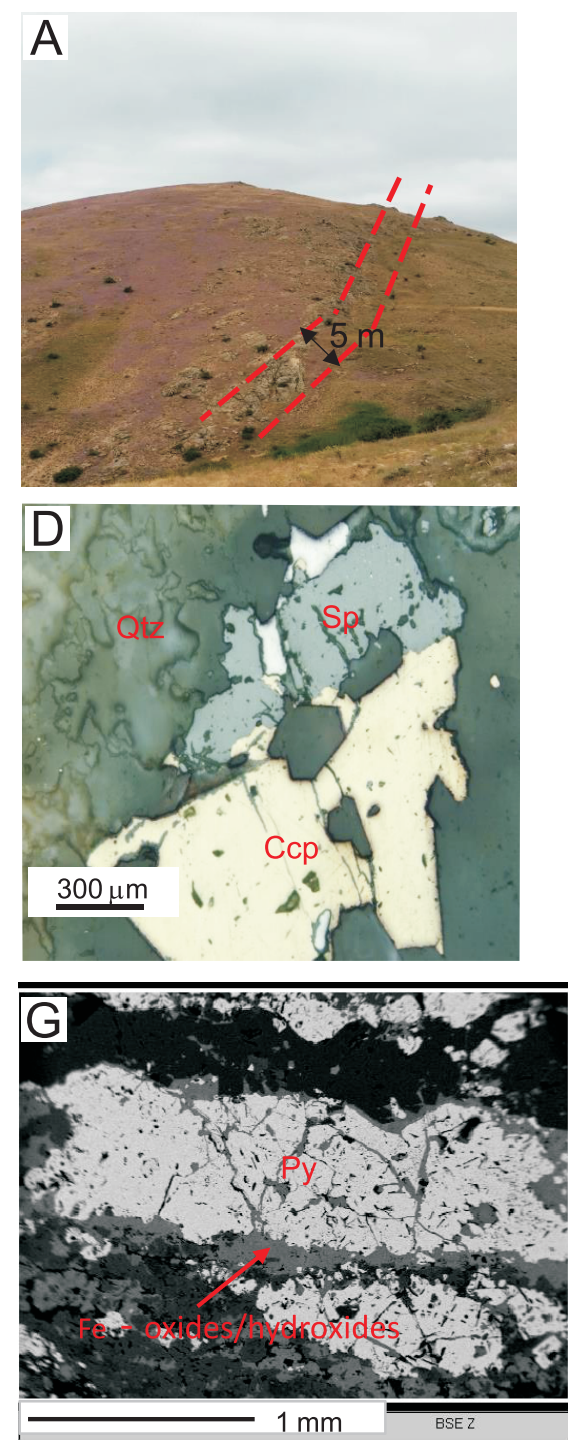
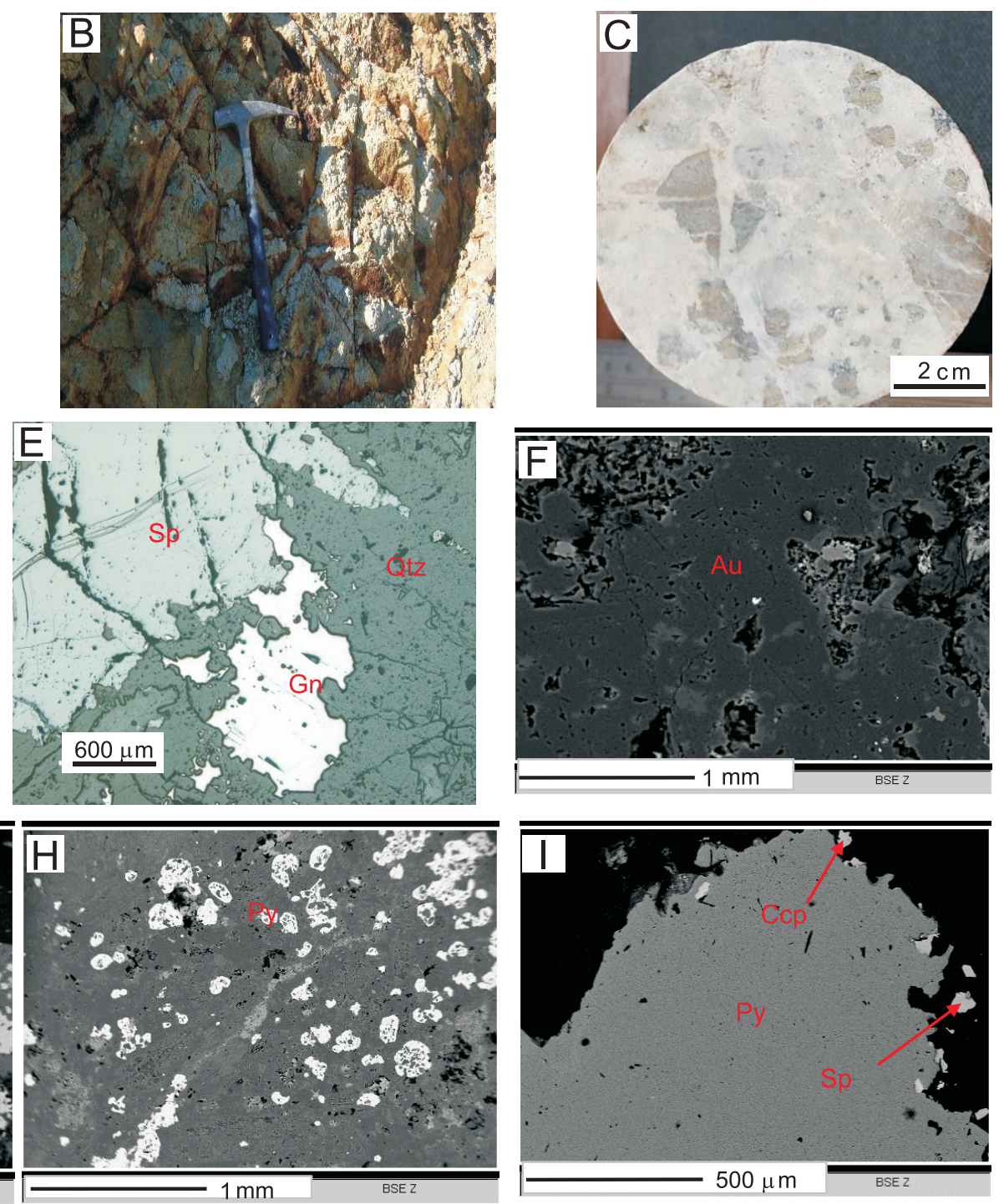

Fig. 8. Field photographs (A and B), hand specimen (C) and microphotographs of ore (D-I)

A - outcrop of a vein composed mostly of quartz and Fe-oxides-hydroxides in silicified wall rocks in Mazra'eh Shadi deposit; B - outcrop of stockwork of copper-bearing mineralisation in quartz monzodiorite porphyry at Mazra'eh Shadi; C - breccia texture in drill core section; D paragenesis of sphalerite and chalcopyrite (reflected light) in main mineralisation stage; $\mathbf{E}$ - paragenesis of galena and sphalerite (reflected light) in main mineralisation stage; $\mathbf{F}$ - native gold in quartz vein (microcrystalline); $\mathbf{G}$ - pyrite and Fe-oxides as fracture-fillings in quartz; $\mathbf{H}$ aggregate of spherical pyrite enclosed in quartz (pre-main mineralisation stage); I - paragenesis of pyrite, chalcopyrite and sphalerite in the main mineralisation stage; F-I - (backscatter electron image); Au - gold, Py - pyrite, Ccp - chalcopyrite, Sp - sphalerite, Gn - galena, Qtz quartz

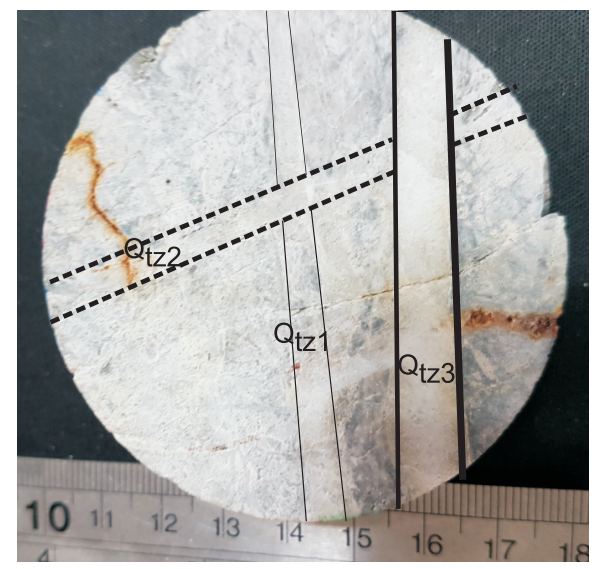

Fig. 9. Three main generations of quartz veins: Qtz1 - early (pre-main mineralization, low in Au), Qtz2 - intermediate (main ore assemblage) resulting from gentle boiling, with high $\mathrm{Au}$, Qtz3 - a late stage (post-main mineralization, Au poor), Qtz quartz, scale in centimetres 
1994; Dong et al., 1995; Craig, 2001; Chauvet et al., 2006; Christie et al., 2007).

Mineral textures that can indicate a sequence of precipitation include pseudomorphs, intergrowths, inclusions of different origin (exsolution, relicts) and growth zonation, among others. The degree of overstepping of equilibrium conditions is recorded by the different form of a mineral, as has been shown experimentally (Okamoto et al., 2010). Different rates of mineral growth and the variable balance between the rates of the multiple steps in the reaction pathways on the atomic scale of grain nucleation and growth is reflected by changing forms. Silica minerals, in particular quartz, are characterized by specific properties (e.g., crystal shape, colour, trace element and isotopic composition) which are related to the geological history and specific conditions existing at the time of formation of this hydrothermal ore deposit.

Many chemical and physical properties of quartz and other silica polymorphs, such as trace element content, isotopic composition, etc., are determined by their structure (Götze and Zimmerle, 2000; Götze, 2009). These different properties of quartz and other silica minerals result in the existence of numerous varieties, i.e. polymorphs. Numerous studies have shown that quartz of different origin can be distinguished by distribution and shape of inclusions, temperature of homogenization, and chemical composition of fluid inclusions.

Vein textures in the Mazra'eh Shadi deposit were examined at various scales, from microscopic to mesoscopic (hand specimens). Analysis over a broad size range is necessary to understand thoroughly the information contained in the rock (Craig, 2001). Such studies provide an indication of textural changes in a single sample, as well as textural differences between samples in different locations, on the scale of centimetres to hundreds of metres. Such characteristics show the spatial diversity of quartz textures, including those favouring gold mineralisation, at depths up to shallow levels or surface. Five textures (crustiform, comb, microcrystalline, cockade, and mosaic) are distinguished from field reconnaissance and hand specimen observation at the Mazra'eh Shadi deposit. Samples have been collected from surface and drill core samples (Hen-07 borehole in an Au-Ag-bearing quartz vein). Examples of quartz textures observed in the Mazra'eh Shadi deposit and their position in the classification of Dong et al. (1995) are shown in Figure 10.

Primary textures observed in the studied quartz veins are oscillatory zoned euhedral crystals, chalcedonic and spheroidal textures, and mosaic quartz. The most common texture in the hydrothermal quartz veins includes oscillatory euhedral growth zones that vary in thickness and shape (Götze et al., 1999; Lehmann et al., 2009). Mosaics of fine-grained interlocking crystals of quartz result from rapid quartz precipitation upon pressure drop in hydrothermal systems (Rusk and Reed, 2002). This texture may be derived from recrystallisation or mineral replacement.

\section{FLUID INCLUSIONS}

Homogenization temperatures (Th) of fluid inclusions in epithermal deposits range from 100 to $350^{\circ} \mathrm{C}$, with $90 \%$ of the data between $\sim 120$ and $310^{\circ} \mathrm{C}$ (Bodnar et al., 2014). The microthermometric data and calculated parameters, such as salinities, homogenization temperatures, and ice-melting temperatures, density and size for 106 liquid-rich and vapour-rich fluid inclusions, are shown in Figure 11.

Both base and precious metal deposits show a mode in Th at the $\sim 240-250^{\circ} \mathrm{C}$ span (Bodnar et al., 2014). Salinities range from 0.1 to $<40$ wt. \% equivalent $\mathrm{NaCl}$, clustering of the data be- tween 0.1 and 17 wt. $\% \mathrm{NaCl}$ equivalent, and placing majority of the salinities $<10 w t . \%$ (Fig. 12). Both base and precious metal deposits are dominated by fluids with salinity values less than a few weight percent, although base metal-rich deposits (Fig. 12) tend to have a higher proportion of fluid inclusions with salinities $>3-4$ wt.\%, if compared to the precious metal deposits (Fig. 12). Projection of the fluid inclusion microthermometric data of Mazra'eh Shadi on the Th versus salinity diagram (Fig. 12A, B) indicates their characteristics typical of both base and precious metal deposits, but still dominated by precious metal deposits. Recognition of fluid inclusions trapped under conditions of boiling or immiscibility is valuable for P-T estimations because the homogenization temperatures equal the trapping temperatures (Roedder, 1984).

Epithermal deposits are classified into high-sulphidation, intermediate-sulphidation, and low-sulphidation types according to ore, mineral assemblages, and chemical composition of the parent fluids (Sillitoe et al., 2003).

According to Bodnar et al. (2014), homogenization temperatures and salinities of fluid inclusions in high-sulphidation base and precious metal deposits show a range from 100 to 345 $\pm 15^{\circ} \mathrm{C}$ and 0 to $23 \mathrm{wt} . \% \mathrm{NaCl}$ equivalent, respectively. In intermediate-sulphidation, the base and precious metal deposits show the temperature range of $140-310^{\circ} \mathrm{C}$ and salinities of 0-12 wt. \% NaCl, respectively. Low-sulphidation deposits are almost exclusively precious metal deposits and show a Th range from 120 to $320^{\circ} \mathrm{C}$ and salinity from 0 to $14 \mathrm{wt} . \% \mathrm{NaCl}$, but still most data dominated within the $200-300^{\circ} \mathrm{C}$ and $<5 \mathrm{wt}$. $\%$ salinity range. Plots of salinity versus homogenization temperatures for Mazra'eh Shadi fluid inclusions in Figure 13 (for each sulphidation state: high, intermediate, and low), indicate that the deposit is intermediate with respect to sulphidation.

The base metals to gold ratio increases at depth. Sulphide minerals deposited from primary ore-forming fluids (with the average salinity of $1.34 \mathrm{wt} . \% \mathrm{NaCl}$ equivalent and temperature of $219-281^{\circ} \mathrm{C}$ ). The base-metal sulphide minerals: galena, sphalerite and chalcopyrite, are common. Hydraulic fracturing and a concomitant rapid pressure drop caused boiling that led to outflow of early fluids to a shallower level and evolution toward higher salinity (average $2.49 \mathrm{wt} . \% \mathrm{NaCl}$ equivalent) and lower temperature (Figs. 14 and 15). As this fluid boils and $\mathrm{SO}_{2}$ and $\mathrm{CO}_{2}$ are partitioned into the vapour phase, the remaining liquid carries a surplus of $\mathrm{H}+$, which makes it very acidic $(\mathrm{pH}=1$; Hedenquist et al., 2000). Boiling of an ore fluid in this case will result in loss of $\mathrm{H}_{2} \mathrm{~S}$ to the vapour phase, which causes destabilization of the $\mathrm{Au}(\mathrm{HS})-2$ complex and precipitation of $\mathrm{Au}$. This trend reflects the evolution of fluids and the decrease in temperature with time.The presence of microcrystalline quartz at the Mazra'eh Shadi deposit is consistent with the silica supersaturation.

If Th data in fluid inclusion assemblages are consistent (i.e. $90 \%$ of the Th data concentrate within a $10-15^{\circ} \mathrm{C}$ interval) among inclusions of various sizes and shapes, then the homogenization temperatures of the fluid inclusions record original conditions of entrapment (Goldstein and Reynolds, 1994). Summary of microthermometric data and calculated parameters for primary fluid inclusions (Appendix 2, Fig. 16A) indicate that gradual evolution of hydrothermal fluids took part during formation of the Mazra'eh Shadi deposit.

The effect of concentration of dissolved elements due to losing of volatiles during fluid boiling could result in increased salinities (Henley and McNabb, 1978; Wilkinson, 2001; Meinert et al., 2003; Liao et al., 2014). The evolved fluid had higher salinity (average 2.49 wt.\% $\mathrm{NaCl}$ equivalent) and lower temperature (average $227^{\circ} \mathrm{C}$ ), from which gold precipitated (Fig. 16). Two populations: high-temperature low-salinity, and low-tem- 


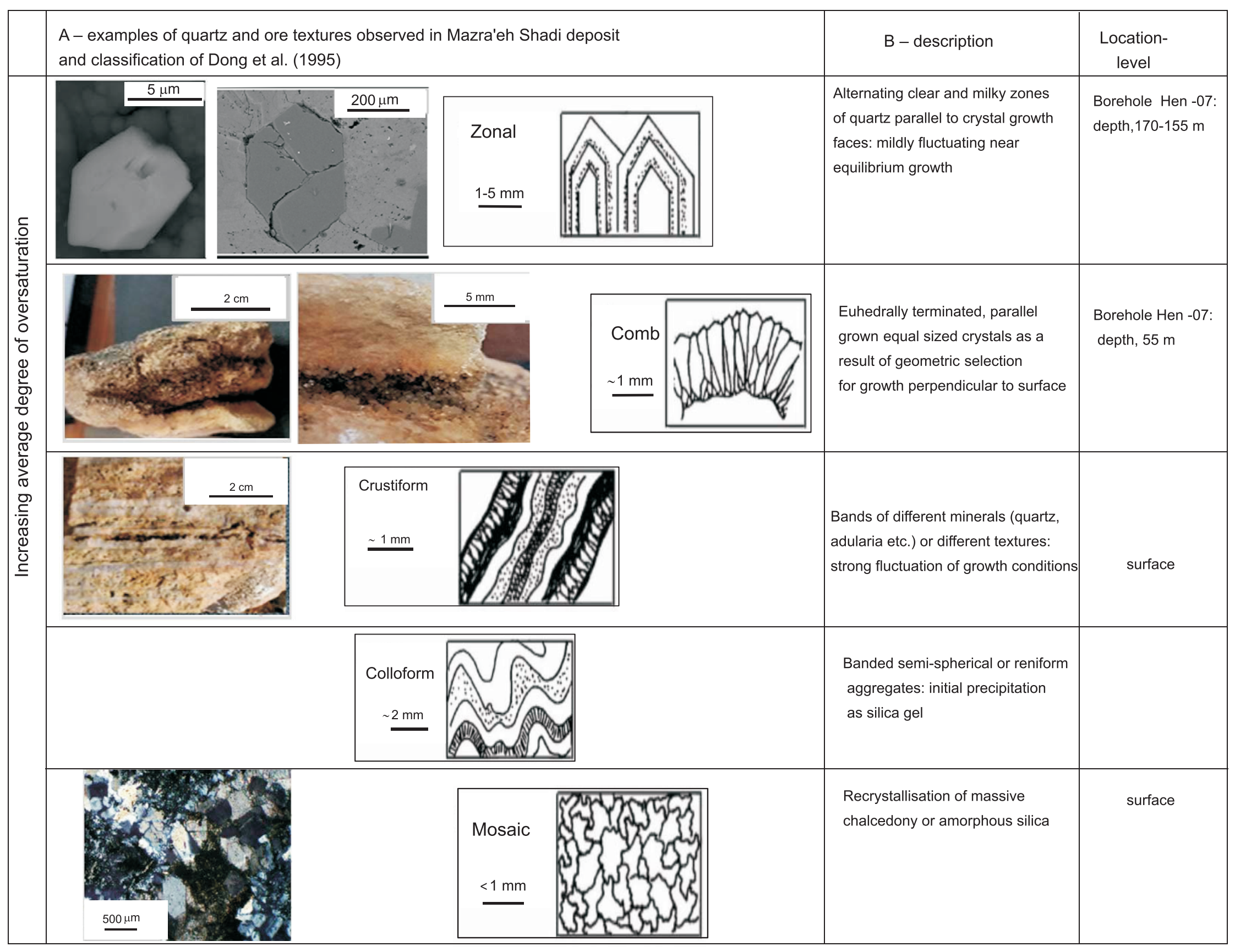

Fig. 10. Comparison of textures of quartz in different levels of Mazra'eh Shadi deposit (left) with classification of Dong et al. (1995) (right) 

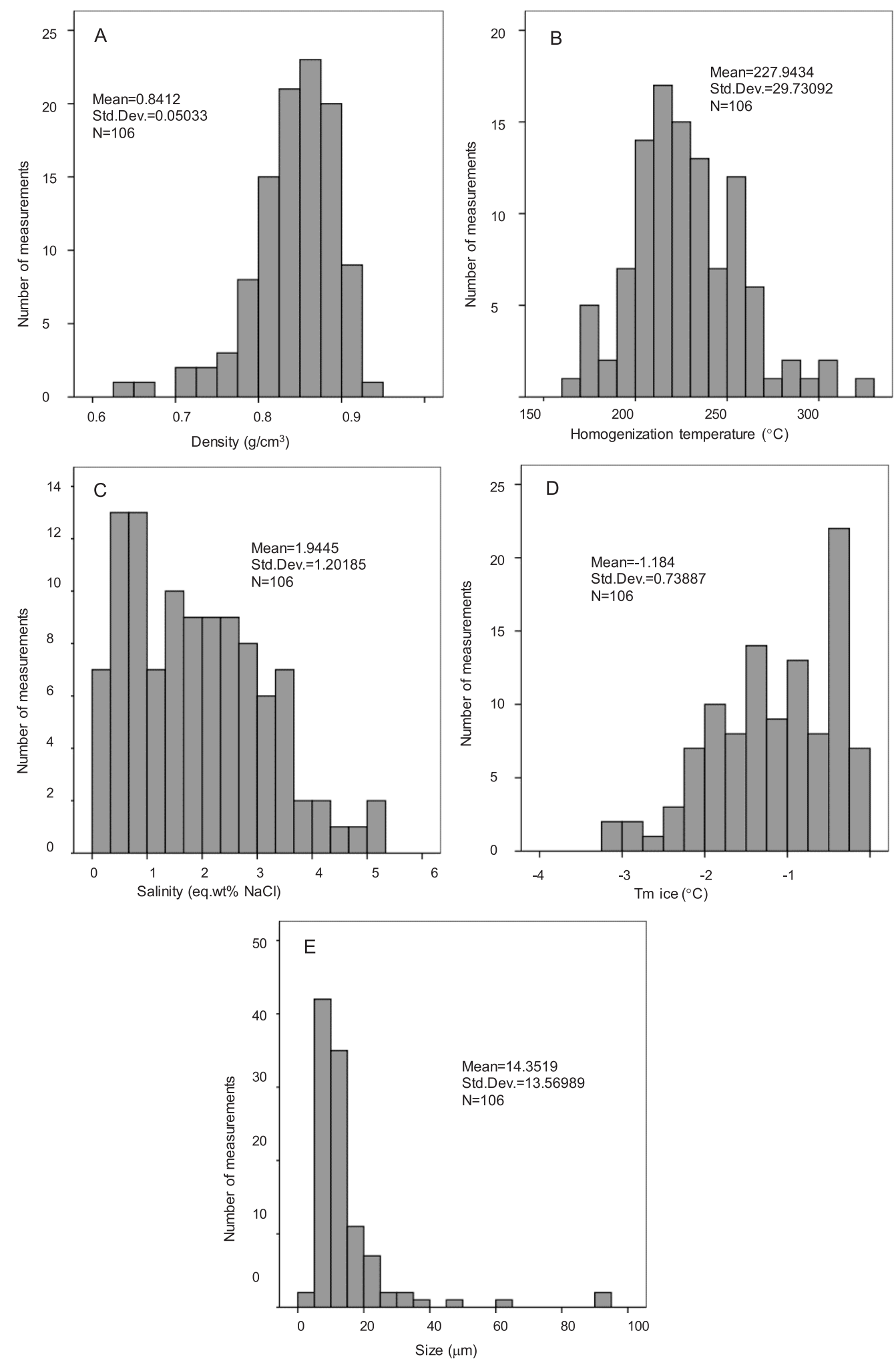

Fig. 11. Histograms of the density (A), homogenization temperature (B), salinity (C), ice melting temperatures (D) and size (E) for 106 studied liquid-rich and vapour-rich fluid inclusions in Mazre'eh Shadi deposit; Mean - arithmetic mean, Std. Dev - standard deviation, Tm ice - ice melting temperatures 

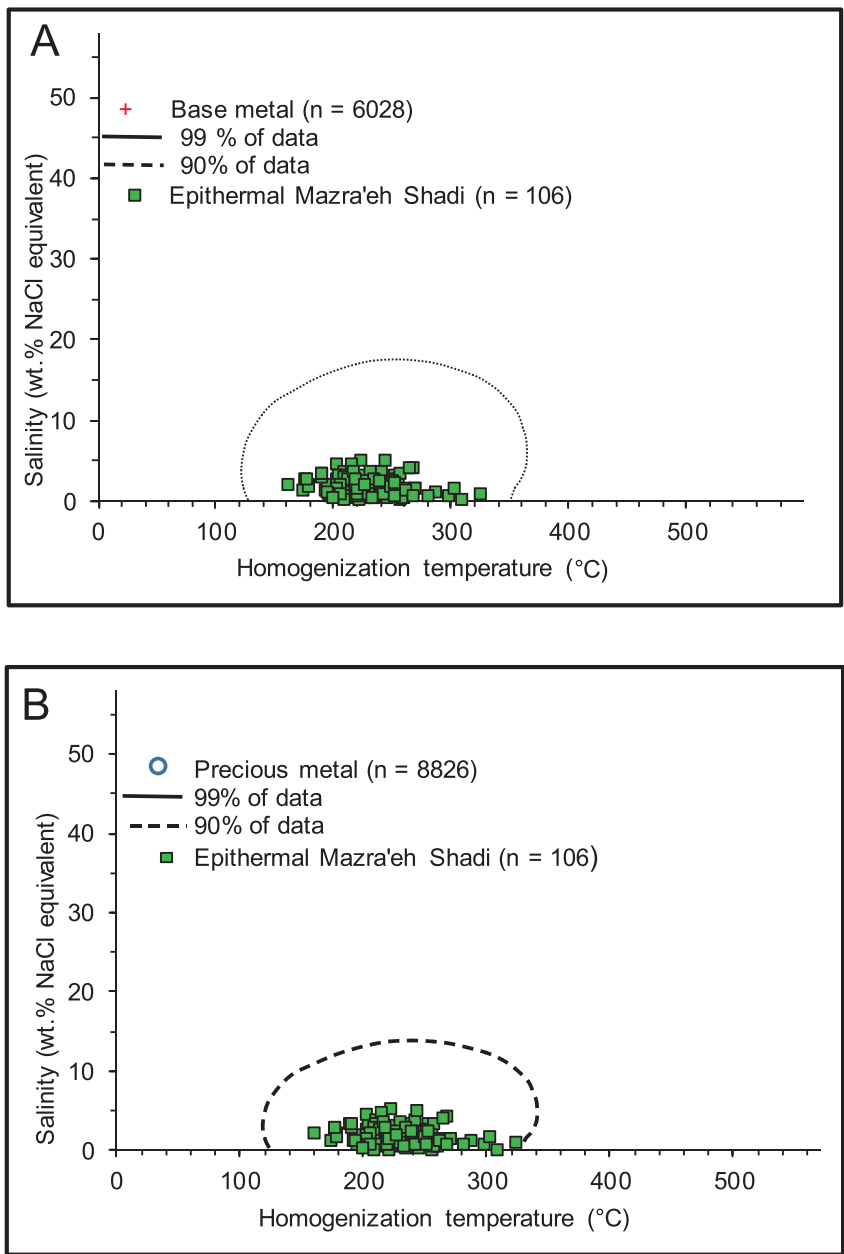

Fig. 12. Summary of published homogenization temperature-salinity pairs from epithermal ore deposits (Bodnar et al., 2014) with microthermometry data of Mazra'eh Shadi fluid inclusions

A - fluid inclusion data from epithermal base metal deposits; B - fluid inclusion data from epithermal precious metal deposits; $\mathrm{n}$ - number of analysed inclusion

perature high-salinity inclusions mark out. This temperature domain corresponds to a depth of 200 to $380 \mathrm{~m}$ below the water table (palaeodepth in Fig. 15). Therefore, the boiling should be considered as the main mechanism responsible for ore deposition at the Mazra'eh Shadi deposit (Fig. 16B). This finding is consistent with coexistence of vapour-rich and liquid-rich inclusions (Fig. 17).

\section{STABLE ISOTOPES}

Sulphur isotopic compositions have been widely used to investigate sulphide and sulphate deposition processes, and as tracers of sulphur sources (e.g., volcanic rocks, magmatic volatiles and sea water). Sulphur isotopic compositions of sulphides of epithermal deposits generally yield $\delta^{34} S$ values ranging from -15 to $5 \%$ depending on their geological settings:

(a) -6 and $+5 \%$ for low-sulphidation with most values close to 0\% (Ohmoto and Rye, 1979; Field and Fifarek, 1985);

(b) -15 to $+8 \%$ for alkaline-hosted epithermal deposits (Richards, 1995);

(c) -10 to $+8 \%$ for high-sulphidation deposits (Arribas, 1995).
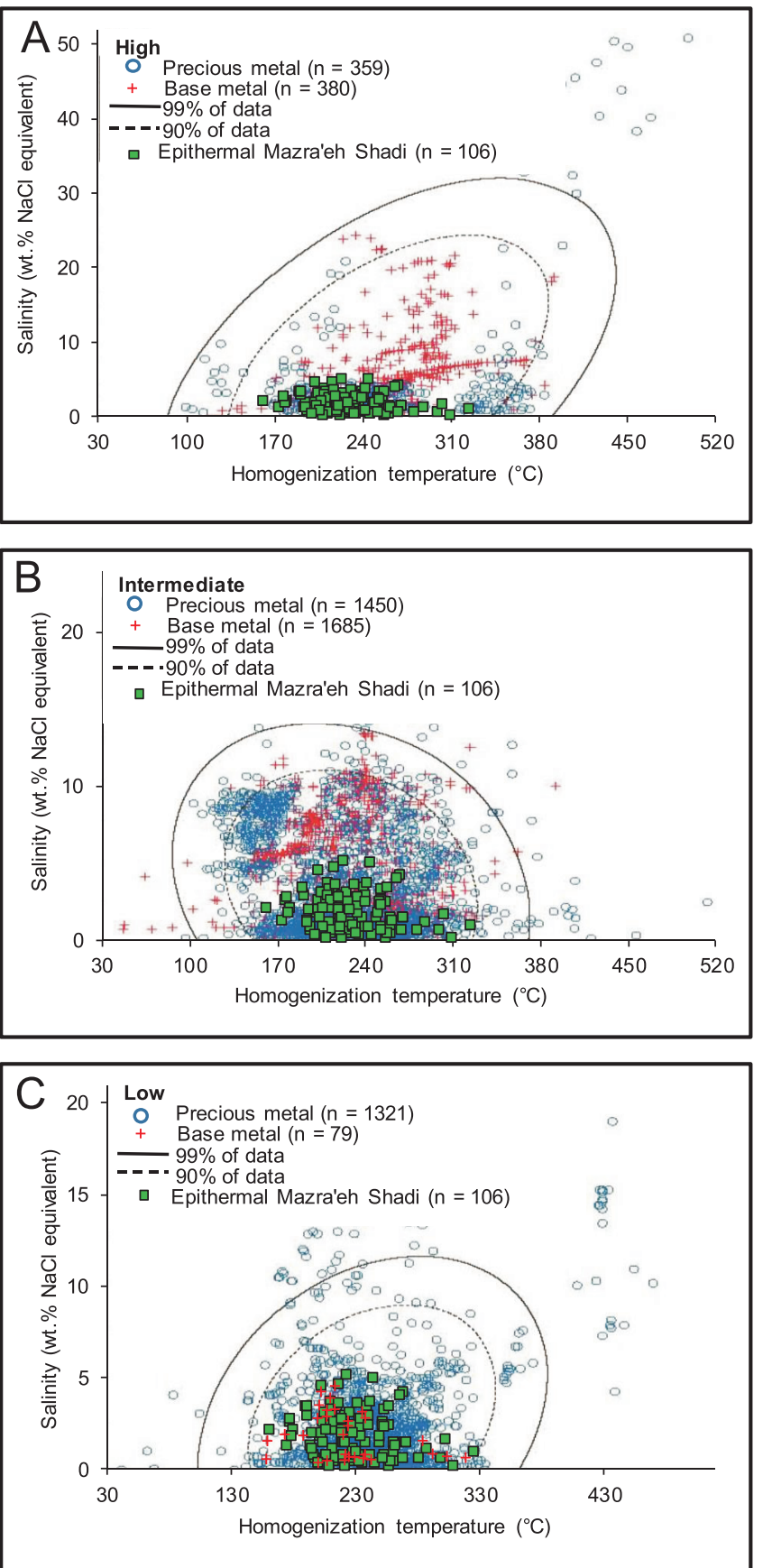

Fig. 13. Comparison of fluid inclusion data for epithermal ore deposits of high (A), intermediate (B), and low (C) sulphidation (Bodnar et al., 2014) with microthermometry data on Mazra'eh Shadi fluid inclusions

For each sulphidation state (high, intermediate, and low), the data are also separated with symbol according to the metal budget in the deposit (base metal-rich versus precious metal-rich); $\mathrm{n}$ - number of analysed inclusions

The sulphur isotopic values of sulphide minerals $(-0.2$ to $0.7 \%$, Fig. 18A) imply that sulphur in the hydrothermal fluids was derived from magmatic volatiles (Rollinson, 1993). Sulphur isotope values for sulphides display a shift in $\delta^{34} S$ from around $0.7 \%$ in deepest levels $(155 \mathrm{~m}$ ) to $-0.2 \%$ surface samples (Table 1 and Fig. 18B). This suggests an increasing role for meteoric water from the deepest levels to shallow level and surface. 


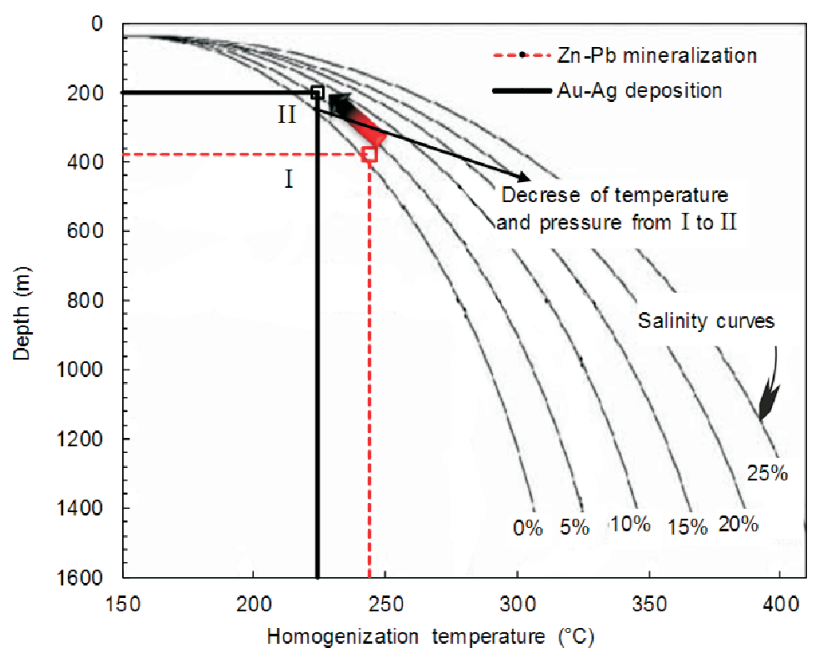

Fig. 14. Plots of homogenization temperatures versus depth for fluid inclusions in borehole Hen-07

General trend from base metal sulphide-dominated (lead and zinc) with high temperature fluid to gold - dominated with low temperature

Several epithermal gold systems are located in $A A B$, such as those of high sulphidation (Masjed Daghi), intermediate sulphidation (Mazra'eh Shadi) and low sulphidation (Zaglic and Safikhanloo). Sulphur isotope values for sulphides show a shift from $\sim 0 \%$ o (1.2 to $-1.1 \%$ o) in Masjed Daghi to increasingly negative in Zaglic and Safikhanloo. The $\delta^{34} S$ values suggest a decreasing role for magmatic fluids from the Masjed Daghi to Mazra'eh Shadi and Zaglic and Safikhanloo epithermal systems, i.e. in the NWW-SEE direction (Fig. 18C).

\section{RELATIONSHIP BETWEEN QUARTZ AND ORE TEXTURES, BOILING, AND METAL DEPOSITION}

Boiling of fluids occurred repeatedly, leading to the solution supersaturation by silica, which resulted in the formation of banded veins with variable quartz textures. Intermittent boiling in epithermal deposits caused repeated sequential precipitation of precious metal minerals with base metal sulphides that are associated with colloform and microcrystalline quartz (Shimizu, 2014). The previous studies at the Mazra'eh Shadi deposit (Ebrahimi et al., 2009, 2011) did not discuss the variation in boiling conditions revealed by the fluid inclusion study.

At Mazra'eh Shadi, quartz veins containing coexisting liquid-rich and vapour-rich inclusions, as a strong evidence of boiling during hydrothermal evolution, have relatively high $\mathrm{Au}$ grades (up to $813 \mathrm{ppb}$ ). This type is common in quartz with crustiform texture at shallow levels and surface.

Identification of degrees of boiling, as evidenced by the fluid inclusion assemblages formed at different stages of the vein quartz precipitation, is particularly important to distinguish between the nonboiling through gentle boiling to intense boiling at the same sample location.

In effect of the detailed microscopic study of fluid inclusions in vein quartz at the Mazra'eh Shadi epithermal deposit three types of fluid inclusion are recognized: (1) type A fluid inclusion assemblage along growth zones in quartz that are indicative of nonboilling conditions; these fluid inclusions are oval; (2) type B fluid inclusion assemblage consisting of coexisting liquid- and vapour-rich inclusions that are indicative of gentle boiling; these inclusions exhibit an oval to irregular shape; (3) type C fluid inclusion assemblage consisting entirely of vapour-rich inclu-

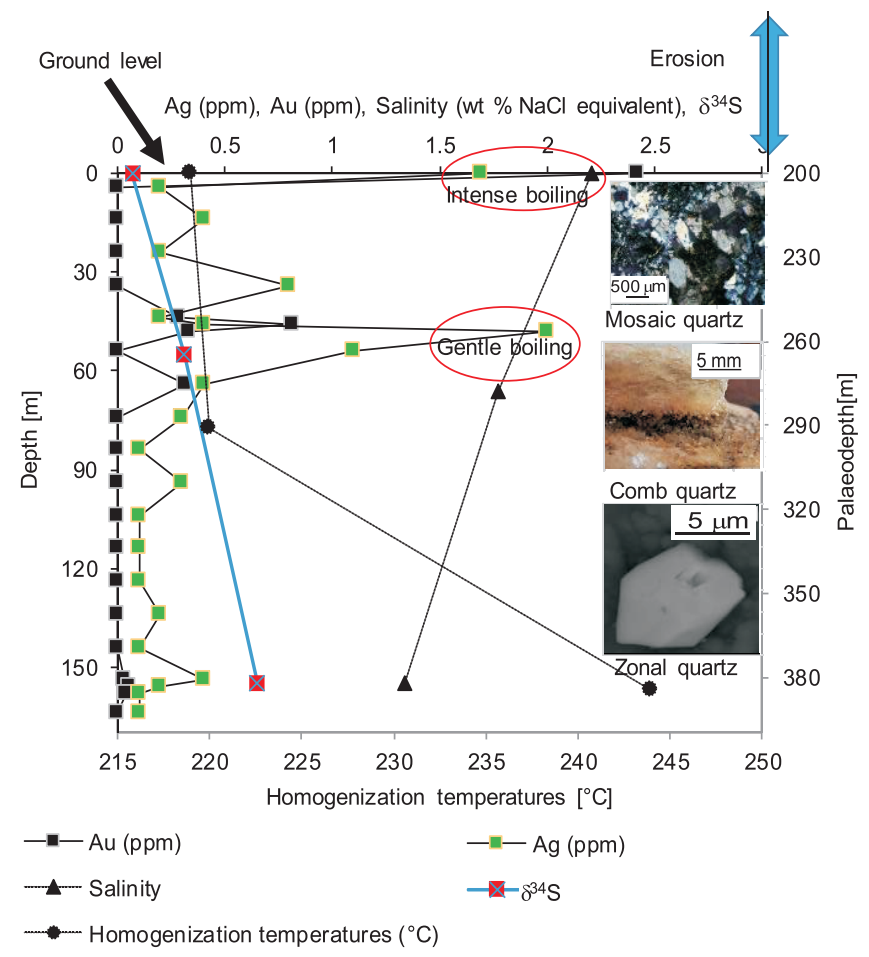

Fig. 15. Plot of $\mathrm{Ag}$, Au, salinity, $\delta^{34} \mathrm{~S}$ and homogenization temperatures against depth in the borehole Hen-07 in Au bearing quartz veins

Location of quartz in Figure 10

sions that are indicative of intense boiling, which exhibit an oval to subrectangular plan shape. Fluid inclusion assemblages in type C at the Mazra'eh Shadi deposit (Fig. 17C) are the result of intense boiling.

The presence of both types of fluid inclusions ( $B$ and $C)$ in the Hen-07-D66 borehole at the $66 \mathrm{~m}$ mine level indicates that the intensity of boiling fluctuated. The homogenization temperatures of the inclusions recorded original conditions of entrapment, if a fluid inclusion analysis yielded consistent Th data (i.e. $90 \%$ of the Th data within a $10-15^{\circ} \mathrm{C}$ interval) among inclusions of various sizes and shapes (Goldstein and Reynolds, 1994). Evidence for gentle boiling or nonboiling conditions is provided by the primary fluid inclusions in zonal and comb quartz. The presence of adularia, blade-shape calcite, and quartz pseudomorphs after this calcite are evidence of local boiling (Browne, 1978; Hedenquist et al., 2000; Simmons and Browne, 2000).

The close association of precious metal minerals and microcrystalline quartz at the Mazra'eh Shadi deposit was likely the result of concomitant precipitation of precious metals and amorphous silica due to intense boiling. This theory is supported by the fact that large amounts of precious metals precipitate with amorphous silica as a consequence of $\mathrm{H}_{2} \mathrm{~S}$ loss due to intense boiling in surface pipes where there are sharp pressure decreases observed in some New Zealand geothermal wells (Brown, 1986).

However, intense boiling is not the only cause for precious metal mineralisation. Gentle boiling may be an indication of lower-grade precious metal precipitation spread over a larger vertical range above the base of the boiling zone, and the highest ore grades may occur at some distance above the base of the boiling zone (Simmons and Browne, 2000; Moncada et al., 2012). At the Mazra'eh Shadi deposit, concentrations of Au-Ag occur mainly within quartz veins at a shallow level in the Hen-07-D66 borehole with gentle boiling (max. 813 ppb Au) and 

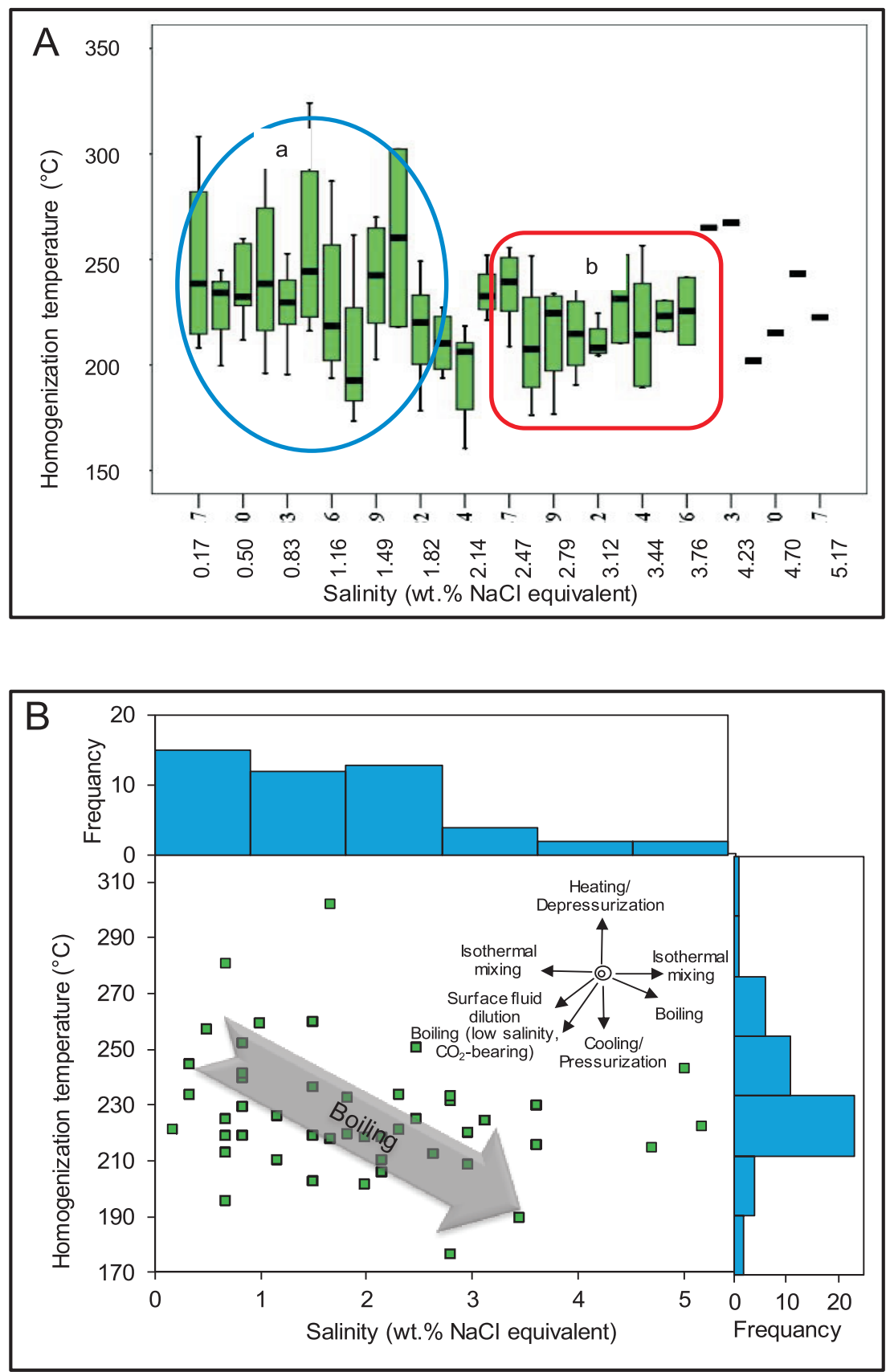

Fig. 16. Plots of homogenization temperatures versus salinity (wt.\% $\mathrm{NaCl}$ equivalent) for fluid inclusions in borehole Hen-07

A - each box shows the median, quartiles, and extreme values within a category; two population, a - high temperature-low salinity and b - low temperature-high salinity; B homogenization temperature versus salinity (wt.\% $\mathrm{NaCl}$ equivalent) in fluid inclusion in borehole Hen-07 (Radmard et al., 2017); arrow represent approximately boiling trend according to model of Wilkinson (Wilkinson, 2001)

in the MSF17 with intense boiling (max. $2420 \mathrm{ppb} A u$ ), whereas lower Au-Ag contents are associated with the base metal-rich deepest levels in the Hen-07-D155 borehole with a nonboiling precipitation environment (max. $52 \mathrm{ppb} \mathrm{Au}$ ).

The evidence of intense and gentle boiling in different stages/substages, as well as the presence of comb and mosaic textures at the same depth in the Mazra'eh Shadi deposit, indicates that the base of the boiling zone likely shifted upward and downward during vein formation. Christie et al. (2007) suggested a relationship between palaeodepths and quartz textures of ma- jor epithermal deposits in New Zealand. Crustiform texture is common at shallow to deep levels and comb texture is characteristic of deep levels, whereas microcrystalline textures are typical at intermediate to deep levels of these epithermal systems. In the Mazra'eh Shadi deposit, crustiform texture is common at shallow levels (indicative of intense boiling), whereas comb textures are typical at shallow and surface levels (indicative of gentle boiling). The presence of mosaic quartz at the Mazra'eh Shadi deposit is consistent with the silica supersaturation and classification of textural features by Dong et al. (1995) (Fig. 10). 


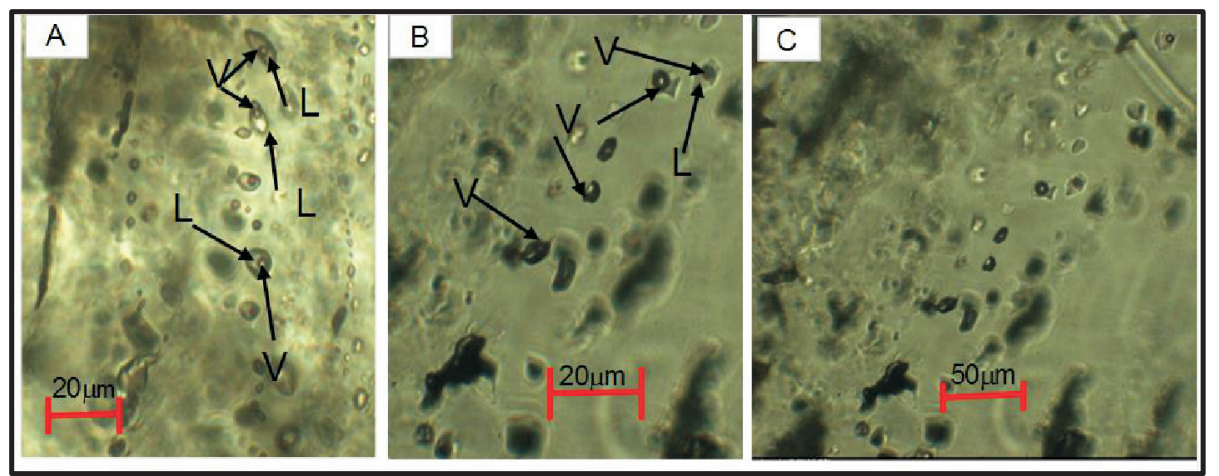

Fig. 17. Fluid inclusion types in quartz from Mazra'eh Shadi deposit

A - fluid inclusion assemblage in quartz, containing liquid-rich inclusions with consistent liquid to vapour ratios that are indicative of nonboiling conditions (borehole Hen-07-D155); B - a fluid inclusion assemblage of coexisting liquid- and vapour-rich inclusions that are indicative of gentle boiling (borehole Hen-07-D66); C - fluid inclusion assemblage of vapour-rich inclusions, which are indicative of intense boiling or generally gas mineral-forming fluid (MSF17); L - liquid, V vapour
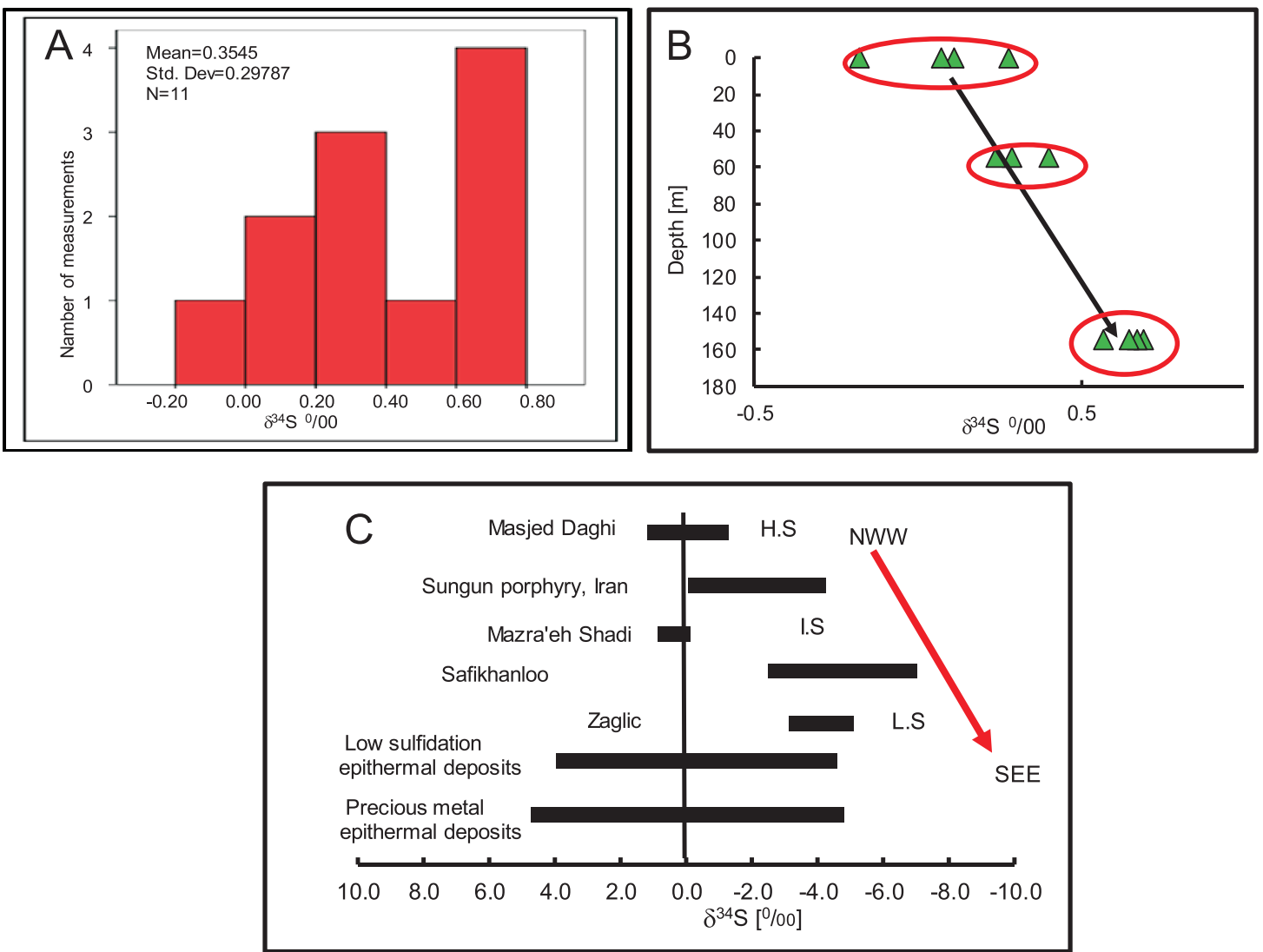

Fig. 18. Distribution of $\delta^{34} \mathrm{~S}$ isotope

A - histogram of sulphur isotope abundance in the Mazra'eh Shadi deposit; B - plots of $\delta^{34} S$ values from Mazra'eh Shadi deposit versus depth; $\mathbf{C}$ - comparison of $\delta^{34}$ S values from Mazra'eh Shadi deposit with Zaglic and Safikhanloo (Ebrahimi et al., 2011), Masjed Daghi (Ebrahimi et al., 2009), low-sulphidation epithermal deposits (Field and Fifarek, 1985), precious metal epithermal deposits (Castor et al., 2003) and Sungun porphyry (Calagari, 2003); NWW-SEE - direction of map in Figure 2 
In the Mazra'eh Shadi deposit the degree of silica supersaturation increases from deep to shallow levels. Distinct are recrystallisation textures that develop inversion of one or more metastable forms of silica to fairly stable quartz and hence records initial precipitation of silica as a metastable form (Herrington and Wilkinson, 1993). Vugs and euhedral growth into space are indicative of open "fissure" space in the veins or may indicate recrystallisation at the period of mineral growth. Pseudomorphic replacements of platy calcite by quartz indicate a change of $\mathrm{pH}$ or other physical and chemical conditions in the vein over the time of mineral precipitation, such that, in the first step, calcite rapidly grew from solution as platy grains so the solution became undersaturated with respect to calcite, and the carbonate was replaced by quartz in the later step. Breccias and veined textures evidence active faulting.

\section{CONCLUSIONS}

1. The Mazra'eh Shadi rock samples are distributed in the subalkaline field of the TAS diagram from dacite to basaltic andesite and show volcanic arc signatures.

2. Microscopically observable features of fluid inclusions in vein quartz reveal three types of parent solutions: intense boiling (common in quartz with crustiform texture), gentle boiling (common in quartz of comb and mosaic textures), and nonboiling within the deposit area.

3. Sulphur isotope values for sulphides display a shift in $\delta^{34} \mathrm{~S}$ from $\sim 0.7 \%$ in the deepest levels $(155 \mathrm{~m})$ to $-0.2 \%$ in surface samples, which suggests an increasing role of meteoric water towards the surface.

4. Projection of salinity versus homogenization temperatures for Mazra'eh Shadi fluid inclusions (for each sulphidation state: high, intermediate, and low) shows that the deposit can be classified as an intermediate epithermal deposit of precious metals.

5. The close association of precious metal carriers and microcrystalline quartz (former amorphous silica) at the Mazra'eh Shadi deposit was likely the result of their concomitant precipitation due to intense boiling.

6. Concentrations of Au-Ag occur mainly within quartz veins in a shallow level with gentle and intense boiling, whereas lower contents of $\mathrm{Au}-\mathrm{Ag}$ are associated with base metals in deep levels where nonboiling conditions occurred.

7. The degree of silica supersaturation increases from deep levels to shallow levels.

Acknowledgements. The authors are grateful to the research committee of Lorestan University and the University of Tabriz for supporting this project. Authors would like to thank the IMIDRO and the Copper Company for technical support.

\section{REFERENCES}

Arribas, Jr. A., 1995. Characteristics of high-sulfidation epithermal deposits, and their relation to magmatic fluid. Mineralogical Association of Canada Short Course, 23: 419-454.

Azizi, H., Jahangiri, H., 2008. Cretaceous subduction - related volcanism in the northern Sanandaj-Sirjan Zone, Iran. Journal of Geodynamics, 45: 178-190

Azizi, H., Moinevaziri, H., 2009. Review of the tectonic setting of Cretaceous to Quaternary volcanism in northwestern Iran. Journal of Geodynamics, 47: 167-179.

Bakker, R.J., 1997. Clathrates: computer programs to calculate fluid inclusion V-X properties using clathrate melting temperatures. Computers and Geosciences UK, 23: 1-18.

Bakker, R.J., 1999. Optimal Interpretation of Microthermometrical Data from Fluid Inclusion, Thermodynamic Modelling and Computer Programming. University Heidelberg, Germany.

Barton, P.B., 1991. Ore textures: problems and opportunities: Mineralogical Magazine, 55: 303-315.

Berberian, M., King, G.C.P., 1982. Towards a paleogeography and tectonic evolution of Iran. Canadian Journal of Earth Sciences, 18: $210-265$.

Blourian, G.H., 1994, Petrology of the tertiary volcanic rocks in the northern of Tehran: M.Sc. thesis, University of Tarbiat Moallem, Tehran, Iran.

Bobis, R.E., 1994. A review of the description, classification and origin of quartz textures in low sulphidation epithermal veins. Journal of the Geological Society of the Philippines, 49: 15-39.

Bobis, R.E., Jaireth, S., Morrison, G.W., 1995. The anatomy of a Carboniferous epithermal ore shoot at Pajingo, Queensland: Setting, zoning, alteration, and fluid conditions. Economic Geology, 90: 1776-1798.

Bodnar, R.J., 1993. Revised equation and table for determining the freezing point depression of $\mathrm{H}_{2} \mathrm{O}-\mathrm{NaCl}$ solutions. Geochimica et Cosmochimica Acta, 57: 683-684.

Bodnar, R.J., Lecumberri-Sanchez, P., Moncada, D., Steele-MacInnis, M., 2014. Fluid Inclusions in Hydrothermal Ore Deposits, Treatise on Geochemistry: 119-142. Elsevier Ltd.
Brown, K.L., 1986. Gold deposition from geothermal discharges in New Zealand. Economic Geology, 81: 979-983.

Brown, P.E., 1989. Flincor: a microcomputer program for the reduction and investigation of fluid-inclusion data. American Mineralogist, 74: 1390-1393.

Browne, P.R.L., 1978. Hydrothermal alteration in active geothermal fields. Annual Review of Earth and Planetary Science, 6: 229-250.

Calagari, A.A., 2003. Stable isotope (S, O, H and C) studies of the phyllic and potassic-phyllic alteration zones of the porphyry copper deposit at Sungun, East Azarbaidjan, Iran. Journal of Asian Earth Sciences, 21: 767-780.

Castor, S.B., Boden, D.R., Henry, C.D., et al., 2003. The Tuscarora $\mathrm{Au}-\mathrm{Ag}$ district: Eocene volcanic-hosted epithermal deposits in the Carlin gold region, Nevada. Economic Geology, 98: 339-366.

Chauvet, A., Bailly, L., Andre, A., Monie, P., Cassard, D., Tajada, F.L., Vargas, J.R., Tuduri, J., 2006. Internal vein texture and vein evolution of the epithermal Shila-Paula district, southern Peru. Mineralium Deposita, 41: 387-410.

Christie, A.B., Simpson, M.P., Brathwaite, R.L., Mauk, J.L., Simmons, S.F., 2007. Epithermal Au-Ag and related deposits of the Hauraki goldfield, Coromandel volcanic zone, New Zealand. Economic Geology, 102: 785-816.

Craig, J.R., 2001. Ore-mineral textures and the tales they tell. Canadian Mineralogist, 39: 937-956.

Daliran, F., Borg, G., Armstrong, R., Vennemann, T., Walther, J., Woodhead, J.D., 2007. Non sulphide zinc deposits, Iran: the hypogene emplacement and supergene modification history of the Angouran zinc deposit, NW-Iran: Series on the Researches on Ore Deposit and Mineral Resources. Report of The German Federal Institute for Geosciences and Natural Resources (BGR), Hannover.

Defant, M.J., Drummond, M.S., 1993. Mount St Helens - potential example of the partial melting of the subducted lithosphere in a volcanic arc. Geology, 21: 547-550. 
Dong, G.Y., Zhou, T., 1996. Zoning in the Carboniferous-Lower Permian Cracow epithermal vein system, central Queensland, Australia. Mineralium Deposita, 31: 210-224.

Dong, G.Y., Morrison, G., Jaireth, S., 1995. Quartz textures in epithermal veins, Queensland - classification, origin, and implication. Economic Geology, 90: 1841-1856.

Dowling, K., Morrison, G.W., 1989. Application of quartz textures to the classification of gold deposits using North Queensland examples. Economic Geology, Monograph, 6: 342-355.

Du Bray, E.A., 2014. Geochemical and modal data for igneous rocks associated with epithermal mineral deposits. U.S, Geological Survey Data Series, 875.

Du Bray, E.A., 2017. Geochemical characteristics of igneous rocks associated with epithermal mineral deposits - review. Ore Geology Reviews, 80: 767-783.

Ebrahimi, S., Alirezaei, S., Pan, Y., 2009. Various epithermal precious metal systems in the Urmieh-Dokhtar magmatic assemblage, Iran. Goldschmidt Conference Abstracts. P. A 318.

Ebrahimi, S., Alirezaei, S., Pan, Y., 2011. Geological setting, alteration, and fluid inclusion characteristics of Zaglic and Safikhanloo epithermal gold prospects, NW Iran. Geological Society Special Publications, 350: 133-147.

Field, C.W., Fifarek, R.H., 1985. Light stable isotope systematics in epithermal systems. Reviews in Economic Geology, 2: 99-128.

Frost, B.R., Barnes, C.G., Collins, W.J., Arculus, R.J., Ellis, D.J., Frost, C.D., 2001. A geochemical classification for granitic rocks. Journal of Petrology, 42: 2033-2048.

Goldstein, R.H., Reynolds, T.J., 1994. Systematics of fluid inclusions in diagenetic minerals. SEPM Short Course, 31: 199.

Götze, J., 2009. Chemistry, textures and physical properties of quartz - geological interpretation and technical application. Mineralogical Magazine, 73: 645-671.

Götze, J., Zimmerle, W., 2000. Quartz and silica as guide to provenance in sediments and sedimentary rocks. Contributions to Sedimentary Petrology, 21, Schweizerbart'sche Verlagsbuchhandlung, Nägele and Obermiller, Stuttgart, $91 \mathrm{~S}$

Götze, J., Plötze, M., Fuchs, H., Habermann, D., 1999. Defect structure and luminescence behavior of agate - results of electron paramagnetic resonance (EPR) and cathodoluminescence (CL) studies. Mineralogical Magazine, 63: 149-163.

Hedenquist, J.W., Arribas, A., Gonzalez-Urien, E., 2000. Exploration for epithermal gold. Reviews in Economic Geology, 13: 245-277.

Henley, R.W., McNabb, A., 1978. Magmatic vapor plumes and ground-water interaction in porphyry copper emplacement. Economic Geology, 73: 1-19.

Herrington, R.J., Wilkinson, J.J., 1993. Colloidal gold and silica in meso thermal vein systems. Geology, 21: 539-542.

Jamalia, H., Dilek, Y., Daliranc, F., Yaghubpurd, A., Mehrabid, B., 2010. Metallogeny and tectonic evolution of the Cenozoic Ahar-Arasbaran volcanic belt, northern Iran. International Geology Review, 52: 608-630.

John, D.A., 2001. Miocene and early Pliocene epithermal gold-silver deposits in the northern Great Basin, Western United States-characteristics, distribution, and relationship to magmatism. Economic Geology, 96: 1827-1853.

Lehmann, K., Berger, A., Götte, T., Ramseyer, K., Wiedenbeck, M., 2009. Growth related zonations in authigenic and hydrothermal quartz characterized by SIMS-, EPMA-, SEM-CL- and SEMCC- imaging. Mineralogical Magazine, 73: 633-644.

Le Maitre, R.W., 2002. Igneous Rocks - a Classification and Glossary of Terms, 2d ed., Cambridge University Press, 236.

Liao, S., Chen, S., Deng, X., Ni, P, Zhao, J., Lioa, R., 2014. Fluid Inclusion characteristics and geological significance of the Xiao copper-tin polymetallic deposit in Gejiu, Yunnan Province. Journal of Asian Earth Science, 79: 455-467.

Meinert, L.D., Hedenquist, J.W., Satoh, H., Matsuhisa, Y., 2003. Formation of anhydrous and hydrous skarn in Cu-Au ore deposits by magmatic fluids. Economic Geology, 98: 147-156.

Moncada, D., Mutchler, S., Nieto, A., Reynolds, T.J., Rimstidt, J.D., Bodnar, R.J., 2012. Mineral textures and fluid inclusions petrography of the epithermal Ag-Au deposits at Guanajuato, Mexico: application to exploration. Journal of Geochemical Exploration, 114: 20-35

Moayyed, M., Ameri, A., Vosoughi Abedini, M., 2008. Petrogenesis of Plio-Quaternary basalts in Azarbaijan, NW Iran and comparisons them with similar basalts in the east of Turkey. Iranian Journal of Crystallography and Mineralogy, 16: 327-340.

Nabavi, M., 1976. An Introduction to the Geology of Iran (in Persian). Geological Survey of Iran Publication.

Nogol-Sadat, 1993. Geology of Iran. Geological Survey of Iran, Iran.

Okamoto, A., Saishu, H., Hirano, N., Tsuchiya, N., 2010. Mineralogical and textural variation of silica minerals in hydrothermal flow-through experiments: implications for quartz vein formation. Geochimica et Cosmochimica Acta, 74: 3693-3706.

Ohmoto, H., Rye, R.O., 1979. Isotopes of sulfur and carbon. In: Geochemistry of Hydrothermal Ore Deposits (ed. H.L. Barnes): 509- 567. Wiley, New York.

Pearce, J.A., Harris, N.B.W., Tindle, A.G., 1984. Trace element discrimination diagrams for the tectonic interpretation of granitic rocks. Journal of Petrology, 25: 956-983.

Radmard, K., Zamanian, H., Hosseinzadeh, M.R., Ahmadi Khalaji, A., 2017. Geochemistry and hydrothermal evolution of ore deposition at the Mazra'eh Shadi -Hizehjan precious and base metal deposit, northeastern Tabriz, Iran. Journal of Mineralogy and Geochemistry, 194: 227-250.

Richards, J., 1995. Alkalic-type epithermal gold deposits - a review. Mineralogical Association of Canada Short Course Series, 23: $367-400$.

Riou, R., 1979. Petrography and Geochemistry of the Volcanic and Plutonic Rocks of the Ahar Quadrangle (Eastern Azarbaijan Iran). University of Saarland.

Roedder, E., 1984. Fluid inclusions. Mineralogical Society of America. Reviews in Mineralogy, 12.

Rollinson, H.R., 1993. Using Geochemical Data: Evaluation, Presentation, Interpretation. Journal of Science and Technology: 306-308.

Rusk, B.G., Reed, M.H., 2002. Scanning electron microscope-cathodoluminescence of quartz reveals complex growth histories in veins from the Butte porphyry copper deposit, Montana. Geology, 30: 727-730.

Saunders, J.A., 1994. Silica and gold textures in bonanza ore of the Sleeper deposit, Humboldt County, Nevada: evidence for colloids and implications for epithermal ore-forming processes, Economic Geology, 89: 628-638.

Shimizu, T., 2014. Reinterpretation of quartz textures in terms of hydrothermal fluid evolution at the Koryu Au-Ag deposit, Japan. Economic Geology, 109: 2051-2065.

Shimizu, T., Matsueda, H., Ishiyama, D., Matsubaya, O., 1998. Genesis of epithermal Au-Ag mineralization of the Koryu mine, Hokkaido, Japan. Economic Geology, 93: 303-325.

Sillitoe, R.H., Hedenquist, J.W., 2003. Linkage between volcanotectonic settings, ore-fluid compositions, and epithermal precious- metal deposits. Society of Economic Geologist, Special Publication, 10: 315-343.

Simmons, S.F., Browne, P.R.L., 2000. Hydrothermal minerals and precious metals in the Broadlands-Ohaaki geothermal system: implications for understanding low-sulfidation epithermal environments. Economic Geology, 95: 971-999.

Simmons, S.F., White, N.C., John, D.A., 2005. Geological characteristics of epithermal precious and base metal deposits. Economic Geology. 100th Anniversary: 485-522.

Sisson, T.W., 1994. Hornblende-melt trace-element partitioning measured by ion microprobe. Chemical Geology, 117: 331-344.

Wilkinson, J.J., 2001. Fluid inclusion in hydrothermal ore deposits. Lithos, 55: 229-272.

Yang, Z.M., Hou, ZQ., Whit, NC., Chang, ZQ., Song, Li, YC., 2009. Geology of the post-collisional porphyry copper-molybdenum deposit at Qulong, Tibet. Ore Geology Reviews, 36: 133-159. 